4

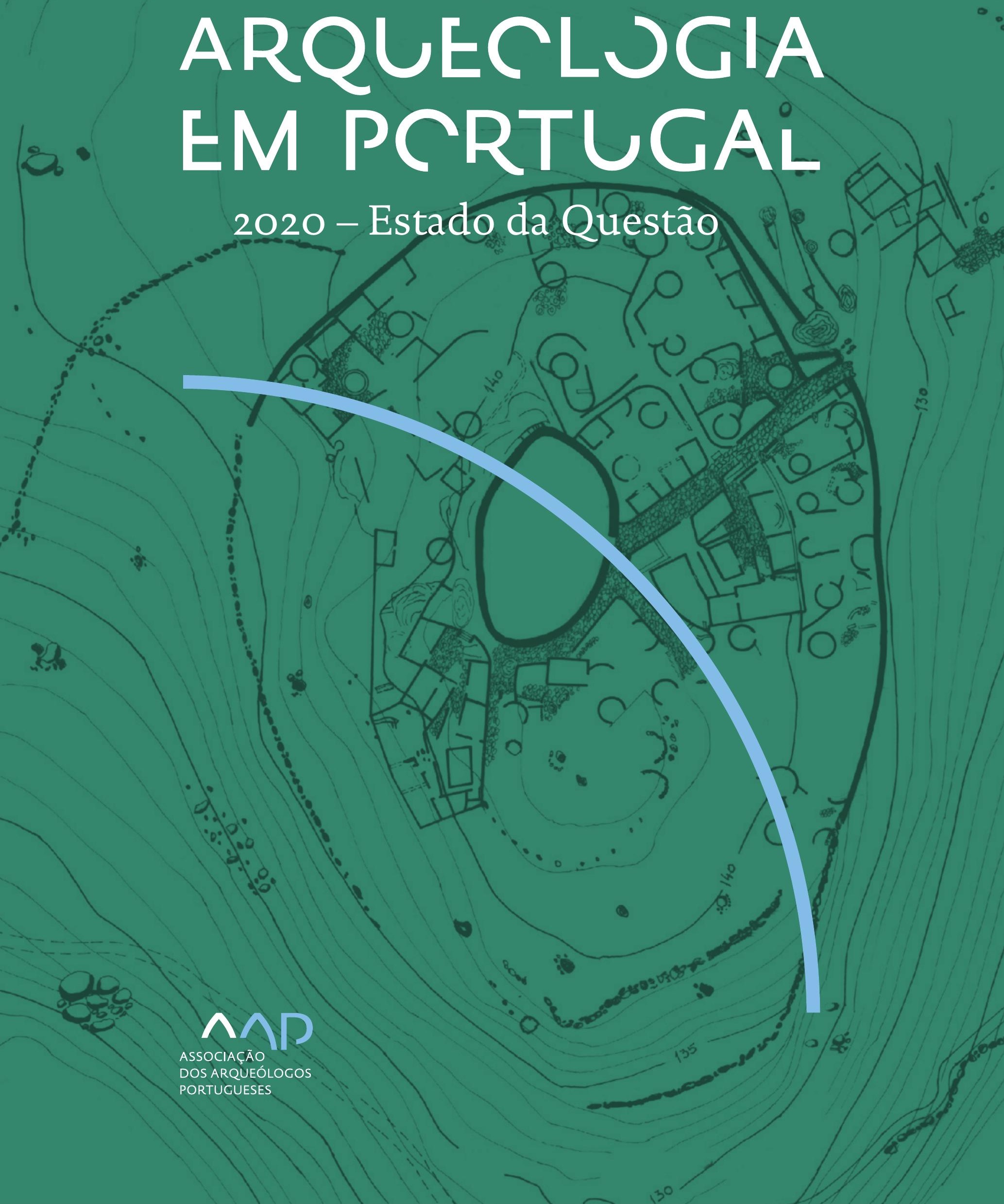


Coordenação editorial: José Morais Arnaud, César Neves e Andrea Martins Design gráfico: Flatland Design

AAP - ISBN: 978-972-9451-89-8

CITCEM - ISBN: 978-989-8970-25-1

Associação dos Arqueólogos Portugueses e CITCEM

Lisboa, 2020

O conteúdo dos artigos é da inteira responsabilidade dos autores. Sendo assim a Associação dos Arqueólogos Portugueses declina qualquer responsabilidade por eventuais equívocos ou questões de ordem ética e legal.

Desenho de capa:

Planta do castro de Monte Mozinho (Museu Municipal de Penafiel).

\section{$\hat{\wedge} \mathrm{P}$}

DOS ARQUEÓLOGOS PORTUGUESES

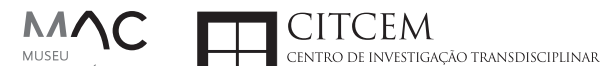
MUSEU
ARQUELLÓGICO
DO CARMO
U.PORTO

FLUP FACULDADE DE LETRAS
UNIVERSIDADE DO PORTO

Apoio

EC para a Ciência 


\section{Índice}

15 Prefácio

José Morais Arnaud

\section{Historiografia e Teoria}

17 Território, comunidade, memória e emoção: a contribuição da história da arqueologia (algumas primeiras e breves reflexões)

Ana Cristina Martins

25 Como descolonizar a arqueologia portuguesa?

Rui Gomes Coelho

41 Arqueologia e Modernidade: uma revisitação pessoal e breve de alguns aspetos da obra homónima de Julian Thomas de 2004

Vítor Oliveira Jorge

57 Dados para a História das Mulheres na Arqueologia portuguesa, dos finais do século XIX aos inícios do século XX: números, nomes e tabelas

Filipa Dimas / Mariana Diniz

73 Retractos da arqueologia portuguesa na imprensa: (in)visibilidades no feminino

Catarina Costeira / Elsa Luís

85 Arqueologia e Arqueólogos no Norte de Portugal Jacinta Bugalhão

101 Vieira Guimarães (1864-1939) e a arqueologia em Tomar: uma abordagem sobre o território e as gentes

João Amendoeira Peixoto / Ana Cristina Martins

115 Os memoráveis? A arqueologia algarvia na imprensa nacional e regional na presente centúria (2001-2019): características, visões do(s) passado(s) e a arqueologia

enquanto marca

Frederico Agosto / João Silva

129 A Evolução da Arqueologia Urbana e a Valorização Patrimonial no Barlavento Algarvio: Os casos de Portimão e Silves

Artur Mateus / Diogo Varandas / Rafael Boavida

\section{Gestão, Valorização e Salvaguarda do Património}

145 O Caderno Reivindicativo e as condições de trabalho em Arqueologia Miguel Rocha / Liliana Matias Carvalho / Regis Barbosa / Mauro Correia / Sara Simões / Jacinta Bugalhão / Sara Brito / Liliana Veríssimo Carvalho / Richard Peace / Pedro Peça / Cézer Santos

155 Os Estudos de Impacte Patrimonial como elemento para uma estratégia sustentável de minimização de impactes no âmbito de reconversões agrícolas Tiago do Pereiro

165 Salvaguarda de Património arqueológico em operações florestais: gestão e sensibilização Filipa Bragança / Gertrudes Zambujo / Sandra Lourenço / Belém Paiva / Carlos Banha / Frederico Tatá Regala / Helena Moura / Jacinta Bugalhão / João Marques / José Correia / Pedro Faria / Samuel Melro

179 Os valores do Património: uma investigação sobre os Sítios Pré-históricos de Arte Rupestre do Vale do Rio Côa e de Siega Verde José Paulo Francisco 
189 Conjugando recursos arqueológicos e naturais para potenciar as visitas ao Geoparque Litoral de Viana do Castelo (Noroeste de Portugal)

Hugo A. Sampaio / Ana M.S. Bettencourt / Susana Marinho / Ricardo Carvalhido

203 Áreas de Potencial Arqueológico na Região do Médio Tejo: Modelo Espacial Preditivo Rita Ferreira Anastácio / Ana Filipa Martins / Luiz Oosterbeek

223 Património Arqueológico e Gestão Territorial: O contributo da Arqueologia para a revisão do PDM de Avis

Ana Cristina Ribeiro

237 A coleção arqueológica do extinto Museu Municipal do Porto - Origens, Percursos e Estudos

Sónia Couto

251 Valpaços - uma nova carta arqueológica

Pedro Pereira / Maria de Fátima Casares Machado

263 Arqueologia na Cidade de Peniche

Adriano Constantino / Luís Rendeiro

273 Arqueologia Urbana: a cidade de Lagos como caso de Estudo Cátia Neto

285 Estratégias de promoção do património cultural subaquático nos Açores. O caso da ilha do Faial

José Luís Neto / José Bettencourt / Luís Borges / Pedro Parreira

297 Carta Arqueológica da Cidade Velha: Uma primeira abordagem

Jaylson Monteiro / Nireide Tavares / Sara da Veiga / Claudino Ramos / Edson Brito /

Carlos Carvalho / Francisco Moreira / Adalberto Tavares

311 Antropologia Virtual: novas metodologias para a análise morfológica e funcional Ricardo Miguel Godinho / Célia Gonçalves

\section{Didáctica da Arqueologia}

327 Como os projetos de Arqueologia podem contribuir para uma comunidade culturalmente mais consciente Alexandra Figueiredo / Claúdio Monteiro / Adolfo Silveira / Ricardo Lopes

337 Educação Patrimonial - Um cidadão esclarecido é um cidadão ativo! Ana Paula Almeida

351 A aproximação da Arqueologia à sala de aula: um caso de estudo no $3^{\circ}$ ciclo do Ensino Básico Luís Serrão Gil

363 Arqueologia 3.o - Pensar e comunicar a Arqueologia para um futuro sustentável Mónica Rolo

377 “Conversa de Arqueólogos" - Divulgar a Arqueologia em tempos de Pandemia Diogo Teixeira Dias

389 Escola Profissional de Arqueologia: desafios e oportunidades Susana Nunes / Dulcineia Pinto / Júlia Silva / Ana Mascarenhas

399 Os Museus de Arqueologia e os Jovens: a oferta educativa para o público adolescente Beatriz Correia Barata / Leonor Medeiros

411 O museu universitário como mediador entre a ciência e a sociedade: o exemplo da secção de arqueologia no Museu de História Natural e da Ciência da Universidade do Porto (MHNC-UP)

Rita Gaspar 
421 Museu de Lanifícios: Real Fábrica de Panos. Atividades no âmbito da Arqueologia Beatriz Correia Barata / Rita Salvado

427 Arqueologia Pública e o caso da localidade da Mata (Torres Novas) Cláudia Manso / Ana Rita Ferreira / Cristiana Ferreira / Vanessa Cardoso Antunes

431 Do sítio arqueológico ao museu: um percurso (também) didático Lídia Fernandes

447 Estão todos convidados para a Festa! E para dançar também... O projecto do Serviço Educativo do Museu Arqueológico do Carmo na $5^{\underline{a}}$ Edição da Festa da Arqueologia Rita Pires dos Santos

459 O “Clã de Carenque”, um projeto didático de arqueologia Eduardo Gonzalez Rocha

469 Mediação cultural: peixe que puxa carroça nas Ruínas Romanas de Troia Inês Vaz Pinto / Ana Patrícia Magalhães / Patrícia Brum / Filipa Santos

481 Didática Arqueológica, experiências do Projeto Mértola Vila Museu Maria de Fátima Palma / Clara Rodrigues / Susana Gómez / Lígia Rafael

\section{Arte Rupestre}

497 Os inventários de arte rupestre em Portugal Mila Simões de Abreu

513 O projeto FIRST-ART - conservação, documentação e gestão das primeiras manifestações de arte rupestre no Sudoeste da Península Ibérica: as grutas do Escoural e Maltravieso Sara Garcês / Hipólito Collado / José Julio García Arranz / Luiz Oosterbeek / António Carlos Silva / Pierluigi Rosina / Hugo Gomes / Anabela Borralheiro Pereira / George Nash / Esmeralda Gomes / Nelson Almeida / Carlos Carpetudo

523 Trabalhos de documentação de arte paleolítica realizados no âmbito do projeto PalæoCôa André Tomás Santos / António Fernando Barbosa / Luís Luís / Marcelo Silvestre / Thierry Aubry

537 Imagens fantasmagóricas, silhuetas elusivas: as figuras humanas na arte do Paleolítico Superior da região do Côa Mário Reis

$55^{1}$ Os motivos zoomórficos representados nas placas de tear de Vila Nova de São Pedro (Azambuja, Portugal) Andrea Martins / César Neves / José M. Arnaud / Mariana Diniz

571 Arte Rupestre do Monte de Góios (Lanhelas, Caminha). Síntese dos resultados dos trabalhos efectuados em 2007-2009 Mário Varela Gomes

599 Gravuras rupestres de barquiformes no Monte de S. Romão, Guimarães, Noroeste de Portugal Daniela Cardoso

613 Círculos segmentados gravados na Bacia do Rio Lima (Noroeste de Portugal): contributos para o seu estudo Diogo Marinho / Ana M.S. Bettencourt / Hugo Aluai Sampaio

631 Equídeos gravados no curso inferior do Rio Mouro, Monção (NW Portugal). Análise preliminar Coutinho, L.M. / Bettencourt, A.M.S / Sampaio, Hugo A.S

645 Paletas na Arte Rupestre do Noroeste de Portugal. Inventário preliminar Bruna Sousa Afonso / Ana M. S. Bettencourt / Hugo A. Sampaio 


\section{Pré-História}

661 O projeto Miño/Minho: balanço de quatro anos de trabalhos arqueológicos Sérgio Monteiro-Rodrigues / João Pedro Cunha-Ribeiro / Eduardo Méndez-Quintas / Carlos Ferreira / Pedro Xavier / José Meireles / Alberto Gomes / Manuel Santonja / Alfredo Pérez-González

677 A ocupação paleolítica da margem esquerda do Baixo Minho: a indústria lítica do sítio de Pedreiras 2 (Monção, Portugal) e a sua integração no contexto regional Carlos Ferreira / João Pedro Cunha-Ribeiro / Sérgio Monteiro-Rodrigues / Eduardo Méndez-Quintas / Pedro Xavier / José Meireles / Alberto Gomes / Manuel Santonja / Alfredo Pérez-González

693 O sítio acheulense do Plistocénico médio da Gruta da Aroeira Joan Daura / Montserrat Sanz / Filipa Rodrigues / Pedro Souto / João Zilhão

703 As sociedades neandertais no Barlavento algarvio: modelos preditivos com recurso aos SIG

Daniela Maio

715 A utilização de quartzo durante o Paleolítico Superior no território dos vales dos rios Vouga e Côa

Cristina Gameiro / Thierry Aubry / Bárbara Costa / Sérgio Gomes / Luís Luís / Carmen Manzano / André Tomás Santos

733 Uma perspetiva diacrónica da ocupação do concheiro do Cabeço da Amoreira (Muge, Portugal) a partir da tecnologia lítica Joana Belmiro / João Cascalheira / Célia Gonçalves

745 Novos dados sobre a Pré-história Antiga no concelho de Palmela. A intervenção arqueológica no sítio do Poceirão I

Michelle Teixeira Santos

757 Problemas em torno de Datas Absolutas Pré-Históricas no Norte do Alentejo Jorge de Oliveira

771 Povoamento pré-histórico nas áreas montanhosas do NO de Portugal: o Abrigo 1 de Vale de Cerdeira Pedro Xavier / José Meireles / Carlos Alves

783 Apreciação do povoamento do Neolítico Inicial na Baixa Bacia do Douro. A Lavra I (Serra da Aboboreira) como caso de estudo Maria de Jesus Sanches

797 O Processo de Neolitização na Plataforma do Mondego: os dados do Sector C do Outeiro dos Castelos de Beijós (Carregal do Sal)

João Carlos de Senna-Martinez / José Manuel Quintã Ventura / Andreia Carvalho / Cíntia Maurício

823 Novos trabalhos na Lapa da Bugalheira (Almonda, Torres Novas) Filipa Rodrigues / Pedro Souto / Artur Ferreira / Alexandre Varanda / Luís Gomes / Helena Gomes / João Zilhão

837 A pedra polida e afeiçoada do sítio do Neolítico médio da Moita do Ourives (Benavente, Portugal)

César Neves

857 Casal do Outeiro (Encarnação, Mafra): novos contributos para o conhecimento do povoamento do Neolítico final na Península de Lisboa.

Cátia Delicado / Carlos Maneira e Costa / Marta Miranda / Ana Catarina Sousa

873 Stresse infantil, morbilidade e mortalidade no sítio arqueológico do Neolítico Final/ Calcolítico ( $4^{\circ}$ e $3^{\circ}$ milénio a.C.) do Monte do Carrascal 2 (Ferreira do Alentejo, Beja) Liliana Matias de Carvalho / Sofia N. Wasterlain 
885 Come together: O Conjunto Megalítico das Motas (Monção, Viana do Castelo) e as expressões Campaniformes do Alto Minho Ana Catarina Basílio / Rui Ramos

899 Trabalhos arqueológicos no sítio Calcolítico da Pedreira do Poio Carla Magalhães / João Muralha / Mário Reis / António Batarda Fernandes

913 O sítio arqueológico de Castanheiro do Vento. Da arquitectura do sítio à arquitectura de um território João Muralha Cardoso

925 Estudo zooarqueológico das faunas do Calcolítico final de Vila Nova de São Pedro (Azambuja, Portugal): Campanhas de 2017 e 2018 Cleia Detry / Ana Catarina Francisco / Mariana Diniz / Andrea Martins / César Neves / José Morais Arnaud

943 As faunas depositadas no Museu Arqueológico do Carmo provenientes de Vila Nova de São Pedro (Azambuja): as campanhas de 1937 a 1967 Ana Catarina Francisco / Cleia Detry / César Neves / Andrea Martins / Mariana Diniz / José Morais Arnaud

959 Análise funcional de material lítico em sílex do castro de Vila Nova de S. Pedro (Azambuja, Portugal): uma primeira abordagem Rafael Lima

971 O recinto da Folha do Ouro 1 (Serpa) no contexto dos recintos de fossos calcolíticos alentejanos

António Carlos Valera / Tiago do Pereiro / Pedro Valério / António M. Monge Soares

\section{Proto-História}

987 Produção de sal marinho na Idade do Bronze do noroeste Português. Alguns dados para uma reflexão

Ana M. S. Bettencourt / Sara Luz / Nuno Oliveira / Pedro P. Simões / Maria Isabel C. Alves / Emílio Abad-Vidal

1001 A estátua-menir do Pedrão ou de São Bartolomeu do Mar (Esposende, noroeste de Portugal) no contexto arqueológico da fachada costeira de entre os rios Neiva e Cávado Ana M. S. Bettencourt / Manuel Santos-Estévez / Pedro Pimenta Simões / Luís Gonçalves

1015 O Castro do Muro (Vandoma/Baltar, Paredes) - notas para uma biografia de ocupação da Idade do Bronze à Idade Média

Maria Antónia D. Silva / Ana M. S. Bettencourt / António Manuel S. P. Silva / Natália Félix

1031 Do Bronze Final à Idade Média - continuidades e hiatos na ocupação de Povoados em Oliveira de Azeméis João Tiago Tavares / Adriaan de Man

1041 As faunas do final da Idade do Bronze no Sul de Portugal: leituras desde o Outeiro do Circo (Beja)

Nelson J. Almeida / Íris Dias / Cleia Detry / Eduardo Porfírio / Miguel Serra

1055 A Espada do Monte das Oliveiras (Serpa) - uma arma do Bronze Pleno do Sudoeste Rui M. G. Monge Soares / Pedro Valério / Mariana Nabais / António M. Monge Soares

1065 São Julião da Branca (Albergaria-a-Velha) - Investigação e valorização de um povoado do Bronze Final

António Manuel S. P. Silva / Paulo A. P. Lemos / Sara Almeida e Silva / Edite Martins de Sá

1083 Do castro de S. João ao Mosteiro de Santa Clara: notícia de uma intervenção arqueológica, em Vila do Conde Rui Pinheiro 
1095 O castro de Ovil (Espinho), um quarto de século de investigação - resultados e questões em aberto

Jorge Fernando Salvador / António Manuel S. P. Silva

1111 O Castro de Salreu (Estarreja), um povoado proto-histórico no litoral do Entre Douro e Vouga

Sara Almeida e Silva / António Manuel S. P. Silva / Paulo A. P. Lemos / Edite Martins de Sá

1127 Castro de Nossa Senhora das Necessidades (Sernancelhe): uma primeira análise artefactual Telma Susana O. Ribeiro

${ }_{1141}$ A cividade de Bagunte. O estado atual da investigação Pedro Brochado de Almeida

1153 Zoomorfos na cerâmica da Idade do Ferro no NW Peninsular: inventário, cronologias e significado Nuno Oliveira / Cristina Seoane

1163 Vasos gregos em Portugal: diferentes maneiras de contar a história do intercâmbio cultural na Idade do Ferro

Daniela Ferreira

1175 Os exotica da necrópole da Idade do Ferro do Olival do Senhor dos Mártires (Alcácer do Sal) no seu contexto regional

Francisco B. Gomes

\section{Antiguidade Clássica e Tardia}

1191 O uso de madeira como combustível no sítio da Quinta de Crestelos (Baixo Sabor): da Idade do Ferro à Romanização Filipe Vaz / João Tereso / Sérgio Simões Pereira / José Sastre / Javier Larrazabal Galarza / Susana Cosme / José António Pereira / Israel Espi

1207 Cultivos de Época Romana no Baixo Sabor: continuidade em tempos de mudança? João Pedro Tereso / Sérgio Simões Pereira / Filipe Santos / Luís Seabra / Filipe Vaz

1221 A casa romana na Hispânia: aplicação dos modelos itálicos nas províncias ibéricas Fernanda Magalhães / Diego Machado / Manuela Martins

1235 As pinturas murais romanas da Rua General Sousa Machado, n. ${ }^{5}$ 1, Chaves José Carvalho

1243 Trás do Castelo (Vale de Mir, Pegarinhos, Alijó) - Uma exploração agrícola romana do Douro

Tony Silvino / Pedro Pereira

1255 A sequência de ocupação no quadrante sudeste de Bracara Augusta: as transformações de uma unidade doméstica Lara Fernandes / Manuela Martins

1263 Os Mosaicos com decoração geométrica e geométrico-vegetalista dos sítios arqueológicos da área do Conuentus Bracaraugustanus. Novas abordagens quanto à conservação, restauro, decoração e datação Maria de Fátima Abraços / Licínia Wrench

1277 “Casa Romana” do Castro de São Domingos (Cristelos, Lousada): Escavação, Estudo e Musealização Paulo André de P. Lemos

1291 A arqueobotânica no Castro de Guifões (Matosinhos, Noroeste de Portugal): O primeiro estudo carpológico

Luís Seabra / Andreia Arezes / Catarina Magalhães / José Varela / João Pedro Tereso 
1305 Um Horreum Augustano na Foz do Douro (Monte do Castelo de Gaia, Vila Nova de Gaia) Rui Ramos

1311 Ponderais romanos na Lusitânia: padrões, formas, materiais e contextos de utilização Diego Barrios Rodríguez

1323 Um almofariz centro-itálico na foz do Mondego

Marco Penajoia

1335 Estruturas romanas de Carnide - Lisboa Luísa Batalha / Mário Monteiro / Guilherme Cardoso

1347 O contexto funerário do sector da "necrópole NO" da Rua das Portas de S. Antão (Lisboa): o espaço, os artefactos, os indivíduos e a sua interconectividade na interpretação do passado Sílvia Loja, José Carlos Quaresma, Nelson Cabaço, Marina Lourenço, Sílvia Casimiro, Rodrigo Banha da Silva, Francisca Alves-Cardoso

${ }_{1361}$ Povoamento em época Romana na Amadora - resultados de um projeto pluridisciplinar Gisela Encarnação / Vanessa Dias

1371 A Arquitectura Residencial em Mirobriga (Santiago do Cacém): contributo a partir de um estudo de caso Filipe Sousa / Catarina Felício

${ }_{1385}$ O fim do ciclo. Saneamento e gestão de resíduos nos edifícios termais de Mirobriga (Santiago do Cacém)

Catarina Felício / Filipe Sousa

1399 Balsa, Topografia e Urbanismo de uma Cidade Portuária Vítor Silva Dias / João Pedro Bernardes / Celso Candeias / Cristina Tété Garcia

1413 No Largo das Mouras Velhas em Faro (2017): novas evidências da necrópole norte de Ossonoba e da sua ocupação medieval Ricardo Costeira da Silva / Paulo Botelho / Fernando Santos / Liliana Nunes

1429 Instrumentos de pesca recuperados numa fábrica de salga em Ossonoba (Faro) Inês Rasteiro / Ricardo Costeira da Silva / Paulo Botelho

1439 A Necrópole Romana do Eirô, Duas Igrejas (Penafiel): intervenção arqueológica de 2016 Laura Sousa / Teresa Soeiro

1457 Ritual, descarte ou afetividade? A presença de Canis lupus familiaris na Necrópole Noroeste de Olisipo (Lisboa)

Beatriz Calapez Santos / Sofia Simões Pereira / Rodrigo Banha da Silva / Sílvia Casimiro / Cleia Detry / Francisca Alves Cardoso

1467 Dinâmicas económicas em Bracara na Antiguidade Tardia Diego Machado / Manuela Martins / Fernanda Magalhães / Natália Botica

1479 Cerâmicas e Vidros da Antiguidade Tardia do Edifício sob a Igreja do Bom Jesus (Vila Nova de Gaia) Joaquim Filipe Ramos

1493 Novos contributos para a topografia histórica de Mértola no período romano e na Antiguidade Tardia Virgílio Lopes

\section{8. Época Medieval}

1511 Cerâmicas islâmicas no Garb setentrional "português": algumas evidências e incógnitas Constança dos Santos / Helena Catarino / Susana Gómez / Maria José Gonçalves / Isabel Inácio / Gonçalo Lopes / Jacinta Bugalhão / Sandra Cavaco / Jaquelina Covaneiro / Isabel Cristina Fernandes / Ana Sofia Gomes 
1525 Contributo para o conhecimento da cosmética islâmica, em Silves, durante a Idade Média Rosa Varela Gomes

1537 Yábura e o seu território - uma análise histórico-arqueológica de Évora entre os séculos VIII-XII José Rui Santos

1547 A encosta sul do Castelo de Palmela - resultados preliminares da escavação arqueológica Luís Filipe Pereira / Michelle Teixeira Santos

1559 A igreja de São Lourenço (Mouraria, Lisboa): um conjunto de silos e de cerâmica medieval islâmica

Andreia Filipa Moreira Rodrigues

1571 O registo material de movimentações populacionais no Médio Tejo, durante os séculos XII-XIII. Dois casos de "sunken featured buildings", nos concelhos de Cartaxo e Torres Novas Marco Liberato / Helena Santos / Nuno Santos

1585 O nordeste transmontano nos alvores da Idade média. Notas para reflexão Ana Maria da Costa Oliveira

1601 Sepulturas escavadas na rocha do Norte de Portugal e do Vale do Douro: primeiros resultados do Projecto SER-NPVD

Mário Jorge Barroca / César Guedes / Andreia Arezes / Ana Maria Oliveira

1619 "Portucalem Castrum Novum" entre o Mediterrâneo e o Atlântico: o estudo dos materiais cerâmicos alto-medievais do arqueossítio da rua de D. Hugo, nํ. 5 (Porto) João Luís Veloso

1627 A Alta Idade Média na fronteira de Lafões: notas preliminares sobre a Arqueologia no Concelho de Vouzela

Manuel Luís Real / Catarina Tente

1641 Um conjunto cerâmico medieval fora de portas: um breve testemunho aveirense Susana Temudo

${ }_{1651}$ Os Lóios do Porto: uma perspetiva integrada no panorama funerário da Baixa Idade Média à Época Moderna em meios urbanos em Portugal

Ana Lema Seabra

1659 O Caminho Português Interior de Santiago como eixo viário na Idade Média Pedro Azevedo

1665 Morfologia Urbana: Um exercício em torno do Castelo de Ourém André Donas-Botto / Jaqueline Pereira

1677 Intervenção arqueológica na Rua Marquês de Pombal/Largo do Espírito Santo (Bucelas, Loures)

Florbela Estêvão / Nathalie Antunes-Ferreira / Dário Ramos Neves / Inês Lisboa

1691 O Cemitério Medieval do Poço do Borratém e a espacialidade funerária na cidade de Lisboa Inês Belém / Vanessa Filipe / Vasco Noronha Vieira / Sónia Ferro / Rodrigo Banha da Silva

1705 Um Espaço Funerário Conventual do séc. XV em Lisboa: o caso do Convento de São Domingos da Cidade Sérgio Pedroso / Sílvia Casimiro / Rodrigo Banha da Silva / Francisca Alves Cardoso

\section{9. Época Moderna e Contemporânea}

1721 Arqueologia Moderna em Portugal: algumas reflexões críticas em torno da quantificação de conjuntos cerâmicos e suas inferências históricas e antropológicas Rodrigo Banha da Silva / André Bargão / Sara da Cruz Ferreira

1733 Faianças de dois contextos entre os finais do século XVI e XVIII do Palácio dos Condes de Penafiel, Lisboa

Martim Lopes / Tomás Mesquita 
1747 Um perfil de consumo do século XVIII na foz do Tejo: O caso do Mercado da Ribeira, Lisboa Sara da Cruz Ferreira / Rodrigo Banha da Silva / André Bargão

1761 Os Cachimbos dos Séculos XVII e XVIII do Palácio Mesquitela e Convento dos Inglesinhos (Lisboa)

Inês Simão / Marina Pinto / João Pimenta / Sara da Cruz Ferreira / André Bargão / Rodrigo Banha da Silva

1775 "Tomar os fumos da erua que chamão em Portugal erua sancta». Estudo de Cachimbos provenientes da Rua do Terreiro do Trigo, Lisboa

Miguel Martins de Sousa / José Pedro Henriques / Vanessa Galiza Filipe

1787 Cachimbos de Barro Caulínitico da Sé da Cidade Velha (República de Cabo Verde)

Rodrigo Banha da Silva / João Pimenta / Clementino Amaro

1801 Algumas considerações sobre espólio não cerâmico recuperado no Largo de Jesus (Lisboa) Carlos Boavida

1815 Adereços de vidro, dos séculos XVI-XVIII, procedentes do antigo Convento de Santana de Lisboa (anéis, braceletes e contas)

Joana Gonçalves / Rosa Varela Gomes / Mário Varela Gomes

1837 Da ostentação, luxo e poder à simplicidade do uso quotidiano: arqueologia e simbologia de joias e adornos da Idade Moderna Portuguesa Jéssica Iglésias

1849 Os amuletos em Portugal - dos objetos às superstições: o coral vermelho Alexandra Vieira

1865 Cerâmicas de Vila Franca de Xira nos séculos XV e XVI Eva Pires

1879 «Não passa por teu o que me pertence». Marcas de individualização associadas a faianças do Convento de Nossa Senhora de Aracoeli, Alcácer do Sal Catarina Parreira / Íris Fragoso / Miguel Martins de Sousa

1891 Cerâmica de Leiria: alguns focos de produção

Jaqueline Pereira / André Donas-Botto

1901 Os Fornos na Rua da Biquinha, em Óbidos Hugo Silva / Filipe Oliveira

1909 A casa de Pêro Fernandes, contador dos contos de D. Manuel I: o sítio arqueológico da Silha do Alferes, Seixal (século XVI) Mariana Nunes Ferreira

1921 O Alto da Vigia (Sintra) e a vigilância e defesa da costa Alexandre Gonçalves / Sandra Santos

1937 O contexto da torre sineira da Igreja de Santa Maria de Loures Paulo Calaveira / Martim Lopes

1949 A Necrópole do Hospital Militar do Castelo de São Jorge e as práticas funerárias na Lisboa de Época Moderna Susana Henriques / Liliana Matias de Carvalho / Ana Amarante / Sofia N. Wasterlain

1963 SAND - Sarilhos Grandes Entre dois Mundos: o adro da Igreja e a Paleobiologia dos ossos humanos recuperados

Paula Alves Pereira / Roger Lee Jesus / Bruno M. Magalhães

1975 Expansão urbana da vila de Cascais no século XVII e XVIII: a intervenção arqueológica na Rua da Vitória no 15 a 17

Tiago Pereira / Vanessa Filipe

1987 Novos dados para o conhecimento do Urbanismo de Faro em época Moderna Ana Rosa 
1995 Um exemplo de Arqueologia Urbana em Alcoutim: o Antigo Edifício dos CTT Marco Fernandes / Marta Dias / Alexandra Gradim / Virgílio Lopes / Susana Gómez Martínez

2007 Palácio dos Ferrazes (Rua das Flores/Rua da Vitória, Porto): a cocheira de Domingos Oliveira Maia

Francisco Raimundo

2021 As muitas vidas de um edifício urbano: História, Arqueologia e Antropologia no antigo Recreatório Paroquial de Penafiel Helena Bernardo / Jorge Sampaio / Marta Borges

2035 O convento de Nossa Senhora da Esperança de Ponta Delgada: o contributo da arqueologia para o conhecimento de um monumento identitário João Gonçalves Araújo / N’Zinga Oliveira

2047 Arqueologia na ilha do Corvo... em busca da capela de Nossa Senhora do Rosário Tânia Manuel Casimiro / José Luís Neto / Luís Borges / Pedro Parreira

2059 Perdidos à vista da Costa. Trabalhos arqueológicos subaquáticos na Barra do Tejo Jorge Freire / José Bettencourt / Augusto Salgado

2071 Arqueologia marítima em Cabo Verde: enquadramento e primeiros resultados do projecto CONCHA

José Bettencourt / Adilson Dias / Carlos Lima / Christelle Chouzenoux / Cristóvão Fonseca / Dúnia Pereira / Gonçalo Lopes / Inês Coelho / Jaylson Monteiro / José Lima / Maria Eugénia Alves / Patrícia Carvalho / Tiago Silva

2085 Trabalhos arqueológicos na Cidade Velha (Ribeira Grande de Santiago, Cabo Verde): reflexões sobre um projecto de investigação e divulgação patrimonial André Teixeira / Jaylson Monteiro / Mariana Mateus / Nireide Tavares / Cristovão Fonseca / Gonçalo C. Lopes / Joana Bento Torres / Dúnia Pereira / André Bargão / Aurélie Mayer / Bruno Zélie / Carlos Lima / Christelle Chouzenoux / Inês Henriques / Inês Pinto Coelho / José Lima / Patrícia Carvalho / Tiago Silva

2103 A antiga fortificação de Quelba / Khor Kalba (E.A.U.). Resultados de quatro campanhas de escavações, problemáticas e perspectivas futuras Rui Carita / Rosa Varela Gomes / Mário Varela Gomes / Kamyar Kamyad

2123 Colónias para homens novos: arqueologia da colonização agrária fascista no noroeste ibérico Xurxo Ayán Vila / José Mạ . Señorán Martín 


\title{
BALSA, TOPOGRAFIA E URBANISMO DE UMA CIDADE PORTUÁRIA
}

\author{
Vítor Silva Dias ${ }^{1}$, João Pedro Bernardes² ${ }^{2}$ Celso Candeias ${ }^{3}$, Cristina Tété Garcia ${ }^{4}$
}

\begin{abstract}
RESUMO
Prospeções geofísicas, sondagens e escavações arqueológicas recentemente levadas a cabo e ainda em curso no âmbito do projeto Balsa, searching the origins of Algarve, têm permitido compilar novos dados científicos sobre a antiga urbe, nomeadamente aferindo o que ainda se preserva e/ou o que já terá sido destruído, a extensão da cidade, algumas das suas realidades urbanísticas e topográficas ou, simplesmente, afastando definitivamente hipóteses de realidades arqueológicas que, comprovadamente, nunca existiram. Assente numa metodologia multivariada e recorrendo a diferentes tecnologias e especialistas, os resultados dos trabalhos já efetuados permitiram atestar que a urbe é mais pequena do que se supunha, estendendo-se por uma estreita faixa ao longo da ria Formosa; permitiram ainda conhecer a orientação da malha urbana, a localização e extensão da sua principal necrópole, a localização do fórum e, provavelmente, do “porto", bem como alguns aspetos da forma como a cidade evoluiu.
\end{abstract}

De uma forma necessariamente muito sintética, dá-se a conhecer o percurso metodológico dos trabalhos realizados, os resultados já obtidos, bem como as expetativas para os trabalhos futuros.

Palavras-chave: Métodos geofísicos, Cidade romana portuária, Sul da Lusitânia, Algarve romano.

\begin{abstract}
Geophysical surveys, field walking prospections and archaeological excavations recently carried out and still ongoing under the project, "Balsa, searching the origins of Algarve", have allowed us to know more about this ancient city, namely by assessing what is still preserved and / or what it will have been destroyed, the extension of the city, some of its urban and topographic realities or, definitively eliminating hypotheses of archaeological realities that, evidently, never existed. Based on a multivariate methodology and using different technologies and specialists, the results of the work already carried out allowed us to attest that the city is smaller than was supposed, extending along a narrow strip along the Ria Formosa; they also allowed to know the orientation of the urban plan, the location and extent of its main necropolis, the location of the forum, as well as some aspects of the way the city has evolved.
\end{abstract}

Keywords: Geophysical methods, Roman town, South Lusitania, Atlantic and Mediterranean, Roman Port City.

\section{O PROJETO DE INVESTIGAÇÃO: «BALSA - EM BUSCA DAS ORIGENS DO ALGARVE»}

Os resultados apresentados enquadram-se no âmbito do projeto: «BALSA - Em Busca das Origens do Algarve» ${ }^{5}$. Avaliado e aprovado pela Fundação da Ciência e Tecnologia e financiado pelo programa operacional do Algarve CRESC 2020, será desenvolvido entre 2019 e 2022, prevendo um conjunto de prospeções geofísicas e sondagens arqueológicas com vista a avaliar o potencial remanescente das ruínas do antigo burgo romano, bem como a sua atual

\footnotetext{
1. CIDEHUS.

2. Universidade do Algarve - CEAACP.

3. C. M. Tavira.

4. DRC Algarve-CEAACP.

5. Sobre o projeto veja-se a respetiva página Web em https://balsa.cvtavira.pt.
} 
real extensão, estando também prevista a realização de ações de divulgação de resultados. Desenvolvido pela Universidade do Algarve e o Centro de Ciência Viva de Tavira, a que se associam o Município de Tavira e a Direção Regional de Cultura do Algarve, surge na sequência das investigações realizadas em 2016-17 no âmbito da minimização de impactes (Dias, Bernardes, Mantas et alii, 2018, fig. 1, p.180) e da Resolução da Assembleia da República no 2007/2017 de 19 de junho (publicado no D.R., $1^{\mathrm{a}}$ série, $\mathrm{n}^{\circ}$ 155/2017 de 11 de agosto), que recomenda ao Governo a preservação das ruínas da antiga cidade romana de Balsa.

O plano de investigação visa, a partir da compilação de toda a informação dispersa e de uma abordagem transdisciplinar (arqueologia, história, geofísica, turismo), estudar a cidade romana de Balsa, clarificando a coexistência milenar das populações no extremo sudoeste da Península Ibérica com comunidades de marítimos que continuamente chegavam a este território. Com recurso a abordagens metodológicas interdisciplinares, procura ainda, especificamente, reconhecer os limites da cidade, bem como as infraestruturas que ainda se preservam, inferindo a importância da cidade e do seu porto. O objetivo principal é, pois, conhecer o que ainda subsiste da cidade romana, os seus limites reais e, finalmente, obter informação concreta que nos permita determinar a importância efetiva desta cidade no contexto das cidades marítimas do sul da Lusitânia.

Procurando comprometer a comunidade local aumentando o impacto social e territorial deste projeto de arqueologia, a componente científica cruza-se, nesta medida, com a formação da comunidade, num exercício de plena ciência cidadã. Através da realização de trabalhos arqueológicos, exposições, formação de operadores turísticos e ações de informação abertas à comunidade, levados a cabo pelo Centro de Estudos em Arqueologia, Artes e Ciências do Património (CEAACP) da Universidade do Algarve, em articulação com o Centro de Ciência Viva de Tavira, a Direção Regional de Cultura do Algarve e o Município de Tavira, espera-se não só recuperar muito da memória perdida desta cidade e das origens do Algarve como, de forma sustentável e integrada, lançar as raízes para a preservação de uma cidade costeira romana articulada na paisagem da Ria Formosa e, com isso, contribuir para a qualificação cultural e identitária da região, onde a natureza, o Património Cultural, a agricultura e a tradição concorrem de for- ma holística para a qualificação inteligente do território e para a sua capacidade atrativa (Figura 1).

Situada no extremo Sudoeste da Península Ibérica, a cidade romana de Balsa é um dos sítios arqueológicos mais importantes e emblemáticos do sul de Portugal ${ }^{6}$. Este sítio preserva ainda testemunhos e elementos de uma longa tradição decorrente de influências mediterrânicas e atlânticas, essenciais para se entender e definir a identidade da região do Algarve. A identificação de algumas estruturas da cidade de Balsa paredes meias com a ria Formosa, como sejam estruturas em opus caementicium e alguns tanques relacionados com atividades produtivas de processamento de peixe situados ao longo da sua margem, bem como um variado espólio com distintas origens e que aqui chega via marítima, vem acentuar a íntima relação que sempre existiu entre o mar, a ria Formosa e as ocupações urbanas do litoral algarvio, numa simbiose entre o elemento natural e cultural que, se excetuarmos raros exemplos (Garcia, 2008) não tem sido devidamente explorado na região (Figura 2) .

\section{OS TRABALHOS DE CAMPO: 2019}

Os trabalhos de escavação/sondagens arqueológicas, no âmbito deste projeto, tiveram o seu início durante o mês de agosto e conclusão em setembro de 2019, tendo sido previamente realizado levantamento fotogramétrico por drone e correspondente modelo digital de terreno (MDT), e modelo de elevação digital, incluindo curvas de nível, posteriormente integrados em plataforma SIG. Graças às sinergias conseguidas com a articulação do projeto internacional "ATLANTIR: del Atlantico al Tirreno", os trabalhos de campo tiveram o contributo de um conjunto de especialistas nacionais e estrangeiros, com destaque para a equipa espanhola de sedimentólogos, petrólogos, paleontólogos e geólogos das Universidades de Huelva, Sevilha e Barcelona. Privilegiou-se a continuidade da validação dos dados geofísicos obtidos anteriormente no âmbito

\footnotetext{
6. Este importante sítio arqueológico foi classificado como Imóvel de Interesse Público pelo Decreto nํㅡㄴ 6 -A/92 de 1 de junho, com Zona Especial de Proteção publicada na Portaria $n^{\circ} 516 / 2011$ de 27 de abril, com atualização recente da classificação para SIP-Sítio de Interesse Público - e aumento da área da ZEP em 9 de maio de 2017, através do Anúncio

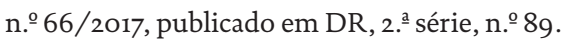


dos estudos de impacte dos trabalhos agrícolas no património arqueológico realizados em 2016/2017 (Figura 3 e 4).

Deste modo, foram continuadas as investigações, que, em 2017, nortearam a implantação da sondagem 4 (S4) e cujos resultados se mostraram inconclusivos quanto à origem (estruturas portuárias? ou outras?) das anomalias ali assinaladas (Dias, Bernardes, Mantas et alii, 2018, p.191-192), efetuando agora sondagens mecânicas (SM1-SM8, ver Figura 2). Por motivos idênticos foi alargada a sondagem 1 (S1, Figura 3 e 4) que revelou o cunhal de um edifício cuja natureza não tinha sido esclarecida (Dias, Bernardes, Mantas et alii, 2018, p. 187-189). Foi ainda aberta uma sondagem sobre a anomalia que a geofísica indiciara como uma estrutura absidada (S6), situada a três dezenas de metros a noroeste da anterior (Dias, Bernardes, Mantas et alii, 2018, fig. 6, p.186), de forma a validá-la como tal, conhecer o seu potencial e definir qual o grau de precisão deste tipo de dados obtidos por métodos não invasivos e correspondente interpretação. Se os resultados da prospeção geofísica em redor da sondagem 1 já tinham sido validados em 2017, tornava-se agora imperioso melhor aferir as relações entre as unidades estratigráficas e determinar as dimensões e orientação destas unidades entre elas e a geomorfologia do sítio. Os resultados de 2019 (Figura 5) revelam com clareza dois momentos construtivos de cronologia distinta nas estruturas murais. Um momento fundacional Alto Imperial [111], com silhares de volumetria generosa e outro, posterior, de cronologia Baixo Imperial [121], edificado em cima do primeiro, com matéria-prima reaproveitada (tégulas e ladrilhos/lateres) em posição visivelmente secundária. Este segundo momento construtivo aproveitando as bases fundacionais do Alto Império está associado a uma fase de pré-abandono da cidade onde os habitantes se apropriaram de espaço público. O exemplo das canalizações tardias [108] e [118], construídas em imbrices a uma cota superior sobre a via [112] já colmatada, demonstram que a transitabilidade do espaço público e correspondente fruição já não existia. Estas canalizações, muito frustres e já parcialmente destruídas pela ação mecânica dos trabalhos agrícolas, corriam, aparentemente, para a ria (Figura 5).

Esta área da cidade indicia, pois, ter tido pelo menos duas fases claramente distintas de ocupação do espaço urbano. Para além das canalizações, também a estrutura mural [117], localizada a norte da via alto- -imperial, a exemplo do que sucede a sul da mesma, na estrutura [121], são erigidas reaproveitando as bases murais alto-imperiais [119] e [111], respetivamente. A estrutura mural [121] e as canalizações [108] e [118] documentam muito bem o reaproveitamento de materiais construtivos, processo típico de maior parte das construções da Antiguidade Tardia, alterando a funcionalidade original dos imbrices para canalizações e a das tégulas para elementos murais. Curiosamente a aplicação das tégulas em cima dos silhares do Alto Império, documenta o momento do arranque da construção tardia, cuja verticalidade poderá ter sido em determinado momento desenvolvida em taipa. Indicia esta possibilidade a orientação/posição e composição da unidade [115]. De qualquer modo, esta interpretação, bem como a identificação da vala fundacional de [111] poderão ser clarificadas nas campanhas vindouras.

Já no limite norte da propriedade, junto à estrada em terra batida que ali passa foi implantada a sondagem 5. Esta resultou da necessidade de esclarecer se os elementos pétreos identificados em fase de acompanhamento arqueológico aquando dos trabalhos agrícolas de 2018 correspondiam a alguma evidência arqueológica, tentando assim caracterizar a sua eventual tipologia. A ausência de georreferenciação dos locais escavados por Estácio da Veiga ${ }^{7}$, aconselhou cautelas metodológicas acrescidas para este sítio. Assim a proximidade com o local da necrópole escavada por Estácio da Veiga recomendou a realização de uma sondagem/limpeza manual no ponto onde apareciam aquelas pedras. Os resultados desta sondagem $\left(\mathrm{S}_{5}\right)$ confirmaram que os elementos pétreos, apesar de sugestivos, não se encontravam in situ nem tinham continuidade em profundidade tendo, aparentemente, sido movidos por meios mecânicos e apresentando-se completamente desconexos e soltos. De qualquer forma a sua natureza e extensão bem como os parcos fragmentos cerâmicos detetados coadunam-se com a existência de uma qualquer estrutura funerária, indiciando que a necrópole escavada pelo pioneiro da arqueologia algarvia se estenderia até aqui (Figura 6).

\footnotetext{
7. No relatório técnico desta intervenção exercitamos a georreferenciação das coordenadas das intervenções de Estácio da Veiga segundo proposta de Carlos Pereira, (Pereira, 2018). De acordo com estes dados o distanciamento desta proposta para a sondagem no 5 regista $175 \mathrm{~m}$ (Bernardes, Dias e Candeias, 2019).
} 
A sondagem 6 (S6, Figura 6) pretendeu validar os anteriores dados da geofísica, cujo local correspondia a uma dupla abside. Tal como o alargamento da sondagem 1 , revelou-se determinante para paulatinamente conhecer com maior rigor a zona ribeirinha situada mais a nascente da Quinta de Torre D'Aires. Demonstrou ser igualmente crucial para aferir o grau de afetação mecânica e de fiabilidade entre as anomalias registadas inicialmente com metodologia geofísica e a natureza das estruturas arqueológicas ainda existentes no subsolo.

A estratigrafia do sítio documenta escasso potencial antrópico, revelando uma unidade estratigráfica superficial de terreno arável sujeita a intensas lavras [6oo] e uma unidade intermédia de sedimento ainda arável [6or], com cerca de $30 / 40 \mathrm{~cm}$, antes de identificados sulcos mecânicos regularizados de considerável dimensão [603] e respetivo enchimento [604]. Os sulcos mecânicos cortam de forma profunda o substrato geológico [612], sendo esclarecedora a exígua verticalidade dos estratos antrópicos e a elevada afetação mecânica de toda a área (cfr. Figura 7,8 e 9 ).

Apesar de muito afetada a estrutura em alvenaria calcária identificada como [605], aparenta corresponder à base de fundação da estrutura mural com morfologia planimétrica em abside identificada nos trabalhos de geofísica. A sua localização, orientação e dimensão coincidem com a interpretação feita durante aqueles trabalhos por Cornelius Meyer (Dias, Bernardes, Mantas et alii, 2018, fig. 6, p.186).

O elevado índice de afetação da estrutura e dos sedimentos que se lhe sobrepunham pressupõe o uso continuado de maquinaria pesada no local. Restando no registo arqueológico praticamente apenas a base fundacional de [605] e um pequeno fragmento dum provável pavimento [6o6], o interesse espacial e estratigráfico do local foi fortemente abalado, tornando no futuro mais pertinente explorar a resposta de outras questões porventura mais reveladoras e coerentes com o estado embrionário da investigação da cidade de Balsa, nomeadamente o profundo grau de afetação e/ou destruição do registo arqueológico em toda a vertente a norte desta sondagem, onde a potência de terras antrópicas é muito reduzida.

Com efeito, a sondagem 6 apesar de certificar a interpretação geofísica e espacial de 2017, atesta igualmente o elevado índice de afetação mecânica de toda esta área. Associando esta informação estratigráfica com os mesmos elementos informativos da sonda- gem 1, tudo indica que por ação mecânica as terras das cotas mais altas tenham sido mecanicamente arroteadas e transportadas seguindo a pendente natural e consequente desnível até à Ria Formosa. O grau de afetação por ação mecânica também está presente no elevado índice de fragmentação no pequeno mas coerente conjunto de materiais recolhidos, onde se destacam pequenos fragmentos de paredes finas e de terra sigillata sudgálica e hispânica que apontam para uma datação alto imperial deste contexto.

Verificando-se uma mobilização de terras pelo uso continuado de meios mecânicos ao longo de décadas na vertente que corre para a ria Formosa onde se localizam as sondagens 1 e 6 (Figura 1), os níveis superficiais de revolvimento identificados na Si terão sido mecanicamente transportados das cotas imediatamente acima, fazendo antever que o índice de preservação das estruturas arqueológicas aumente nas cotas altimétricas mais próximas da Ria Formosa.

Distando as sondagens ( $\mathrm{S}_{1}$ e S6) cerca de $33 \mathrm{~m}$ no sentido SE-NW o espaço que medeia entre elas parece indicar o intervalo a partir do qual aumenta consideravelmente a verticalidade das estruturas preservadas, graças à diminuição de afetação mecânica.

No que se refere às sondagens mecânicas (SM) realizadas na parte ocidental da propriedade, em todas elas é inexistente a presença de ocorrências arqueológicas. A perspetiva do conjunto de todas as intervenções devidamente cartografadas e fotografadas, apresenta uma noção integrada da caracterização estratigráfica da área poente da propriedade (cfr. Figura 2). A ausência de dados arqueológicos não confere com a interpretação da prospeção geofísica e condiciona diretamente a interpretação sobre a extensão da cidade de Balsa, encurtando a sua dimensão para W e provavelmente no sentido W-E se considerarmos o carácter genericamente ortogonal e simétrico que registam as cidades romanas.

A sondagem mecânica $1(\mathrm{SM}$ ), corresponde às imediações da localização da sondagem manual no 4 realizada em 2017, e materializou o tão desejado alargamento dessa sondagem com o objetivo de verificar possíveis lapsos de implantação de coordenadas e definitivamente atestar a presença ou inexistência de estruturas arqueológicas.

A ausência de quaisquer estruturas arqueológicas foi comprovada mecanicamente em extensão (c. de $12 \mathrm{~m}$ no sentido W-E e profundidade de 1,9o $\mathrm{m}$ ) e, apesar das anomalias decorrentes da interpretação dos dados geofísicos, não se confirmou qualquer estrutura 
ou ocorrência de natureza arqueológica e/ou contemporânea. Recorda-se que os dados obtidos por Geo-radar indicavam estruturas a cerca de 6o/8o cm (Dias e Freire, 2017, mapa 12A e 12B, p. 64-65). A realidade sedimentar registou sequência e características estratigráficas idênticas às já identificadas na sondagem manual realizada em 2017 (Figura 10). Confirmou-se, deste modo, que a hipótese de trabalho colocada anteriormente, de possível desfasamento de coordenadas na implantação da sondagem manual n4 4 , não se verifica e que no local não existem quaisquer ocorrências arqueológicas sugeridas pela interpretação geofísica.

Distando da SM1 apenas 4 metros, a SM2 pretendeu igualmente aferir a validade da estrutura circular interpretada pelos dados da geofísica. Também neste caso os resultados estratigráficos confirmam a ausência de dados arqueológicos contradizendo a interpretação da geofísica. O solo regista até esta latitude características dunares e marítimas.

As $\mathrm{SM}_{3}$ e $\mathrm{SM}_{4}$ registaram dados semelhantes, apresentando características sedimentares que denotam uma clara transição para ambiente mais terreste e menos marítimo.

A localização da sondagem mecânica (SM9), distante de qualquer sondagem realizada, pretendeu averiguar as possíveis estruturas ortogonais identificadas em 2017 na fotografia aérea (Dias e Freire, 2017, mapa 1, p. 49). Tal como as restantes sondagens mecânicas apenas foram identificadas unidades sedimentares sem inclusões arqueológicas ou patrimoniais. Afasta-se, assim, a possibilidade de em toda esta área próxima da ribeira da Luz terem existido quaisquer estruturas portuárias, desconhecendo-se, no caso da Balsa, por enquanto, quaisquer dados sobre estruturas portuárias romanas ou sobre elementos de sinalização de apoio à navegação, tão frequentes na costa portuguesa (Fabião, 2014, 102-103).

\section{INTERPRETAÇÃO DOS RESULTADOS}

Considerando os resultados alcançados e apesar da fase embrionária da investigação sugerir, naturalmente, mais questões do que respostas, teve a presente campanha dois principais objetivos. O primeiro visava verificar a existência de estruturas arqueológicas no limite poente da propriedade; o segundo, aferir os índices de afetação na sua parte nascente.

Relativamente ao primeiro objetivo, impôs-se como imperioso averiguar a existência, ou não, de estru- turas portuárias na parte mais ocidental da quinta, junto à ribeira da Luz, onde alguns indicadores (fotografia aérea e métodos de deteção remota, não invasivos) e vária bibliografia sugeria poder situar-se o porto da cidade (Silva, 2007, pp. 68, 98, 100; Mantas, 2016, pp. 40-41) ${ }^{8}$. Foram realizadas 9 extensas sondagens mecânicas, perfazendo um total de c. 120 $\mathrm{m}^{2}$, com recurso a retroescavadora que, durante mais de um dia, sondaram os terrenos onde se situavam os indícios (geofísicos) de estruturas. Sondagem após sondagem, foi-se descartando a possibilidade de existência de qualquer estrutura portuária ou de outra tipologia, bem como de materiais arqueológicos. Os raros fragmentos cerâmicos de origem romana que surgiram, confirmaram-se muito rolados, denotando, claramente, terem sido transportados da sua posição primária. Registo arqueológico contrastante, por exemplo, com a importante área industrial de preparados de peixe associada a fragmentos anfóricos nos lodos da zona ribeirinha de Ossonoba (Viegas, 2011; Bernardes, 2012; Bernardes, 2017b), cuja densidade de fragmentos identificados mais se parece assemelhar à zona escavada por Manuel e Maria Maia (Maia \& Maia, 1978), apesar das intensas afetações mecânicas ainda documentada nas prospeções de 2016 e 2017 (Dias, Bernardes, Mantas et alii, 2018, fig.3, p. 183).

A realidade sedimentar e a ausência de estruturas portuárias a poente, claramente contradiz a interpretação dos dados da prospeção geofísica (Dias e Freire, 2017, mapas 12A, 12B, 12C, p. 64-66). O registo estratigráfico permitiu traçar um padrão coerente entre as sondagens sendo possível definir espacialmente quais são as sondagens com matriz sedimentar marítima (SM1; SM5; SM6; SM7) e quais as sondagens com matriz terreste ( $\mathrm{SM}_{2} ; \mathrm{SM}_{3} ; \mathrm{SM}_{4}$; $\left.\mathrm{SM} 8\right)$. Os perfis estratigráficos são genericamente associados a unidades de cariz geológico com cronologia recente como os depósitos dunares eólicos e as rochas sedimentares (margas) correspondentes a antigos depósitos marinhos e lacustres de material clástico. O carácter excecional que o porto de Balsa poderia significar na estratégia portuária da costa da Lusitânia onde essencialmente se privilegiariam as condições naturais e não a construção estruturada e artificial de apoios à atracagem ou ancoradouro (Mantas,

8. Sobre a sequência dos trabalhos arqueológicos e geofísicos, bem como as expetativas sobre o potencial deste sítio vide também Dias, Bernardes, Mantas et alii, 2018, 191. 
2017, p. 185) também não se confirmou. A abertura das sondagens permitiu reconhecer os limites da antiga ria através dos fundos lodosos que apareceram, cuja natureza e extensão impossibilitavam a existência de qualquer porto no local, conforme foi confirmado pela equipa de geólogos e sedimentólogos de várias universidades espanholas que se deslocaram ao local.

Face a estes dados, fica completamente descartada a possibilidade da cidade romana de Balsa se estender até junto da ribeira da Luz, devendo o seu limite mais ocidental situar-se no fim do declive da colina que cai para o vale daquela linha de água. A identificação de algumas sepulturas tardias nesta área, em 2017 (Dias, Bernardes, Mantas et alii, 2018, fig. 12, pp.19o-191), reforça a ideia de que os limites ocidentais da cidade se situariam por esta longitude. A presença desta necrópole, distando cerca de 275 $\mathrm{m}$ do local da sondagem 4 (e da SMi), onde a geofísica interpretava a presença de fundações estruturais, que se pensavam com provável funcionalidade portuária, reforça a possibilidade da cidade ser mais curta para $\mathrm{W}$ do que inicialmente se pensou depois da interpretação dos resultados geofísicos. Quanto às anomalias detetadas remotamente e algumas também visíveis em fotografia aérea, é plausível explicá-las através de alterações no solo provocadas por intensos revolvimentos mecânicos, eventualmente associados à implantação de sistemas de rega nas últimas décadas aliás bem identificados em uma das sondagens (SM 6) e pontualmente visíveis à superfície entre SM4 e SM8.

$\mathrm{Na}$ ausência de novos dados, e pressupondo que a necrópole a que correspondem as sepulturas identificadas em 2017 poderá significar o limite $\mathrm{W}$ da cidade de Balsa, as estruturas portuárias certamente que se localizaram noutro local que não o interpretado/ sugerido pelos dados da geofísica e que não foram atestados, quer pela sondagem manual 4 de 2017 , quer pelo alargamento mecânico da mesma sondagem em 2019: SM1, SM 2, SM 3 e SM 7.

Descartada a presença de estruturas arqueológicas na parte mais ocidental da propriedade, sugere-se que o porto de eleição da cidade se situasse na proximidade do fórum, onde dados geomorfológicos e fontes orais documentam a presença de um cais. De resto, e por uma questão prática, é bem conhecida a tendência dos fora das cidades marítimas se situarem próximo dos locais de acesso a partir do mar, como é o caso da vizinha cidade de Ossonoba (Bernardes 2017b).
Para a credibilização desta hipótese contribuem a proximidade das cetárias escavadas por Manuel Maia e Maria Maia (Maia \& Maia, 1978), bem como o registo de maior presença de recipientes de armazenamento em toda esta zona aquando dos trabalhos de prospeção sistemática de superfície (Dias, Bernardes, Mantas et alii, 2018, fig. 3, p.183). A importância económica, da pesca, do sal e da produção dos preparados de peixe nas cidades ribeirinhas da Lusitânia com boas condições portuárias, ocupou papel de grande destaque nestas comunidades (Fabião 20oo; 2006), influenciando diretamente não só a dinâmica exportadora, como a dieta alimentar e o urbanismo (Bernardes, 2015). As dificuldades na identificação do local de implantação do porto de Balsa esbarram quer na obtenção de novos dados preferencialmente com metodologia multidisciplinar, quer na variada tipologia de soluções "naturais" aplicada na seleção dos "portos” romanos (Mantas, 2016).

Em relação ao outro grande objetivo destas intervenções, avaliar o grau de destruição e, consequentemente, aferir a existência, ou não, de ruínas pertencentes à antiga cidade, verificou-se, de forma clara, o nível e a profundidade de afetação das estruturas romanas provocada pelas práticas agrícolas.

Nas duas sondagens abertas na parte oriental da Quinta (Si e S6), observou-se que o terreno foi rompido e ripado por escarificador de máquina de rastos até $70 / 80 \mathrm{cms}$ de profundidade. Assim, todas as estruturas soterradas a profundidades inferiores foram destruídas ou seriamente afetadas (cfr. figuras $6,7,8,9)$. É o caso do grande edifício com dupla abside revelado pela prospeção geofísica e parcialmente detetado na sondagem 6 , que poderia ter pertencido a um complexo termal ou edifício de grandes dimensões, cujos alicerces, a pouca profundidade, foram parcialmente arrancados pela ripagem do terreno, vendo-se bem as marcas dos dentes mecânicos (rippers) no solo e camada geológica (S6).

Estas mesmas marcas estão igualmente bem documentadas no registo estratigráfico e sedimentar de S1, com cerca de $35 \mathrm{~m}^{2}$ e situada na vertente mais perto da ria. No entanto, como a potência de terras aqui é muito maior, praticamente o processo de arroteamento afetou apenas o topo das estruturas arqueológicas que se conservaram até ao século XX (cfr. fig. 3).

Nesta sondagem (SI), a partir dos $70 \mathrm{~cm}$ de profundidade, deteta-se ainda uma canalização e restos de muros romanos tardios (datáveis a partir dos sécs. 
III/IV) que assentam em estruturas murais de época anterior, de boa construção, que definem um entroncamento de ruas. A altura conservada destes muros é variável, podendo atingir cerca de $80 \mathrm{~cm}$. $\mathrm{O}$ conjunto destas estruturas correspondem a uma fachada alinhada do lado sul de uma rua, que corre no sentido Este/Oeste, e o que parece ser o entroncamento de uma segunda rua perpendicular à primeira, vendo-se uma esquina da mesma e o seu entaipamento por estruturas tardias.

Como a intervenção neste primeiro ano foi meramente exploratória, ficou por investigar o interior dos edifícios daquela fachada sul ou as edificações relacionadas com a outra rua. De qualquer forma, parece claro que a partir de cerca de 50 metros para norte da ria, onde a potência estratigráfica de terra antrópica é relativamente diminuta, as estruturas romanas estão muito afetadas ou simplesmente já não existem. Em contrapartida, na faixa junto à ria Formosa mantém-se ainda um forte potencial arqueológico que tencionamos continuar a conhecer nas próximas campanhas.

Importante também nos anos vindouros seria melhor perceber o que ainda existe nos terrenos a nascente da atual propriedade da Quinta da Torre d'Aires, por onde a malha urbana se estendia. A proposta de intervenção para os próximos anos nestes terrenos por métodos não invasivos e/ou de escavação está necessariamente dependente da autorização dos proprietários e dos arrendatários da(s) propriedade(s).

Quer seja pelas dificuldades inerentes à preservação do registo arqueológico, pelo ritmo dos estudos, ou mesmo por um maior interesse "orientalizante" do tráfego marítimo em detrimento do atlântico, a investigação na região (Bernardes, 2017a) seguiu um rumo que resultou numa secundarização da importância dos ritmos comerciais atlânticos (Fabião 2014; Mantas, 2016; Mantas, 2017). Representa a costa algarvia, onde está localizada a cidade portuária de Balsa, não só, o "pré-Mediterrâneo” de Orlando Ribeiro, ou o prolongamento da Andaluzia Ocidental (Fabião, 2009), mas também, algo aparentemente contraditório cuja dinâmica marítimo-económica e cultural se materializa numa região singular, que funciona ora como fronteira geográfico-administrativa, ora como elo, entre os dois mundos.

Um particular prolongamento do Mare Nostrum até à costa ocidental atlântica (cabo de São Vicente), ou uma marcada gaditanização da costa algarvia (Sousa \& Arruda, 2010), têm sido amplamente debatidos como características regionais, destacando diversos autores o papel de Cádis e a estreita relação deste importante porto com a costa algarvia (Fabião, 200o; Bernardes, 2017b; Mantas, 2017; Sousa \& Arruda, 2010). Fará todo o sentido pormenorizar, no futuro, o papel de cidades portuárias como Balsa, na dinâmica comercial marítima entre Bética, Lusitânia e Mauritânia Tingitana (Mantas, 1998), documentada já em fase pré-romana tanto na costa algarvia (Arruda, 2001), como nos contatos atlânticos (Fabião, $2014,100)$ e fortemente indiciada pela epigrafia (IRCP). Somente multiplicando os casos de estudo semelhantes ao de Balsa, será possível, por exemplo, melhor compreender aquelas dinâmicas comerciais. Não sendo necessário, por razões históricas resgatar a importância do mar na tradição algarvia ou lusitana, não será, por motivos idênticos, necessário relembrar a importância regional e simbólica, tal como o intrigante e complexo tema das continuidades e descontinuidades da ocupação humana (Fabião, 2009, 559) associado à costa algarvia, à cidade de Balsa e seu porto. Não faltarão por isso, boas razões, nem motivos, para continuar a investigar o urbanismo de Balsa e a sua natural vocação marítima com metodologia arqueológica e abordagens interdisciplinares.

\section{BIBLIOGRAFIA}

ARRUDA, A. M. (2001) - Importações 'púnicas' no Algarve: cronologia e significado, in A. Tavares, M. J. Ferro e J. L. Cardoso (orgs.), Os Púnicos no Extremo Ocidente. Lisboa, pp. 69-98.

BERNARDES, J. P. (2012) - A cidade de Ossónoba e o seu território, Anais do Município de Faro, XXXVII, pp.11-26.

BERNARDES, J. P. (2015) - Consumo e transformação de peixe entre o mundo romano e o islâmico, in S. Gomez Martinez (Coord.), Memória dos Sabores do Mediterrâneo, Campo Arqueológico de Mértola/ Centro de Estudos Arqueológicos das Universidades de Coimbra e Porto. pp. 55-68.

BERNARDES, J. P. (2017a) - O Sul da Lusitânia Romana nos últimos 25 anos: avanços e novas perspetivas de investigação, in T. Nogales Basarrate (ed.), Atas IX Mesa Redonda Internacional de Lusitania Romana: del passado al presente de la investigación / EMuseu Nacional de Arte Romano 29-30 septiembre 2016. Mérida. pp. 275-292.

BERNARDES, J. P. (2017b) - O sistema portuário de Ossonoba, In Juan M. Campos Carrasco, Javier Bermejo Meléndez (eds), Los puertos atlánticos béticos y lusitanos y su relación comercial con el Mediterráneo /. Huelva. Universidad de Huelva. Hispania Antigua, Serie Arqueológica, 7 , pp. 379-398. 
BERNARDES, J.P., DIAS V.S. e CANDEIAS, C. (2019)-Balsa em busca das origens do Algarve (saict-alg/39581/2018). Estação Arqueológica Romana da Luz - Balsa (C.N.S.: 6o). (Dactilografado, disponível na DGPC).

DIAS, V. S.; FREIRE, J. (2017) - Relatório Final. Prospeção sistemática, prospeção geofisica e sondagens arqueológicas na Quinta de Torre d'Aires. Estação arqueológica romana da Luz-Balsa (CNS: 6o). Archaeofactory. Faro (Disponível na DGPC).

DIAS, V.S. e BERNARDES, J. P., MANTAS, V., FREIRE, J. e DORES, T. (2018) - A cidade romana de Balsa: novos dados e algumas problemáticas da prospeção geofísica em meios muito humanizados, in J. P. Bernardes et. alii., Arqueologia Urbana em Centros Históricos, Faro: Universidade do Algarve, pp. 178-195.

FABIAO, C. (200o) - O sul da Lusitania (Algarve Portugues) e a Baetica: concorrencia ou complementaridade?, in Ex Baetica Amphorae, Actas do Congresso Internacional "Conservas, aceite y vino de la Betica en el Imperio Romano. Ecija: 717-730.

FABIÃO, C. (2006) - A exploração de recursos marinhos na Lusitania romana: balanço dos conhecimentos e perspectivas da investigação, in Historia de la pesca en el ámbito del estrecho. I Conferencia internacional, (Puerto de Santa María Cádiz, Junho de 2004), Cádis, pp. 489-529.

FABIÃO, C. (2009) - Cetárias, ânforas e sal, Estudos Arqueológicos de Oeiras. Oeiras: Câmara Municipal de Oeiras, pp. 555-594.

FABIÃO, C. (2014) - Uma história resgatada ao mar. Vestígios de rotas marítimas romanas nas costas portuguesas, in A. Silveira (coord.), O Tempo Resgatado ao Mar. Lisboa: 99-104.

GARCIA, C. (2008) - Cacela, Terra de Levante. Memórias da Paisagem Algarvia, C. M. de Vila Real de Santo António/ Campo Arqueológico de Mértola.

MAIA, M. G. P.; MAIA, M. (1978) - Relatório da Campanha de escavações realizada em Torre de Ares (Tavira) entre 24 de Outubro e 25 de Novembro de 1977 (Datilografado, disponível na DGPC).

MANTAS, V. G. (1998) - Navegação, economia e relações interprovinciais. Lusitânia e Bética, Humanitas, 50: 199-239.

MANTAS, V. G. (2016) - Navegação e Portos no Algarve Romano, AlUlya, XVI, Loulé, pp. 2551.

MANTAS, V. G. (2017) - Navegação, centros urbanos e espaços portuários na Lusitania, in T. Nogales Basarrate (ed.) Atas IX Mesa Redonda Internacional de Lusitania Romana: del passado al presente de la investigación, (Museu Nacional de Arte Romano 29-30 septiembre 2016), Mérida. pp. 179-208.
PEREIRA, C. S. P. (2018) - As Necrópoles Romanas do Algarve: acerca dos espaços da morte no extremo sul da Lusitânia, (Suplemento 9 do O Arqueólogo Português), Lisboa: Museu Nacional de Arqueologia / Imprensa Nacional.

SILVA, L. F. da (2007) - Balsa, Cidade Perdida, Tavira: Campo Arqueológico de Tavira / Câmara Municipal de Tavira.

SOUSA, E. \& ARRUDA, A. M. (2010) - A Gaditanização do Algarve, Mainake, XXXII (II), 951-974. Málaga: Universidad de Málaga.

VIEGAS, C. (2011) - A ocupação romana do Algarve. Estudo do povoamento e economia do Algarve central e oriental no período romano (Estudos e Memórias, 3), Lisboa. 


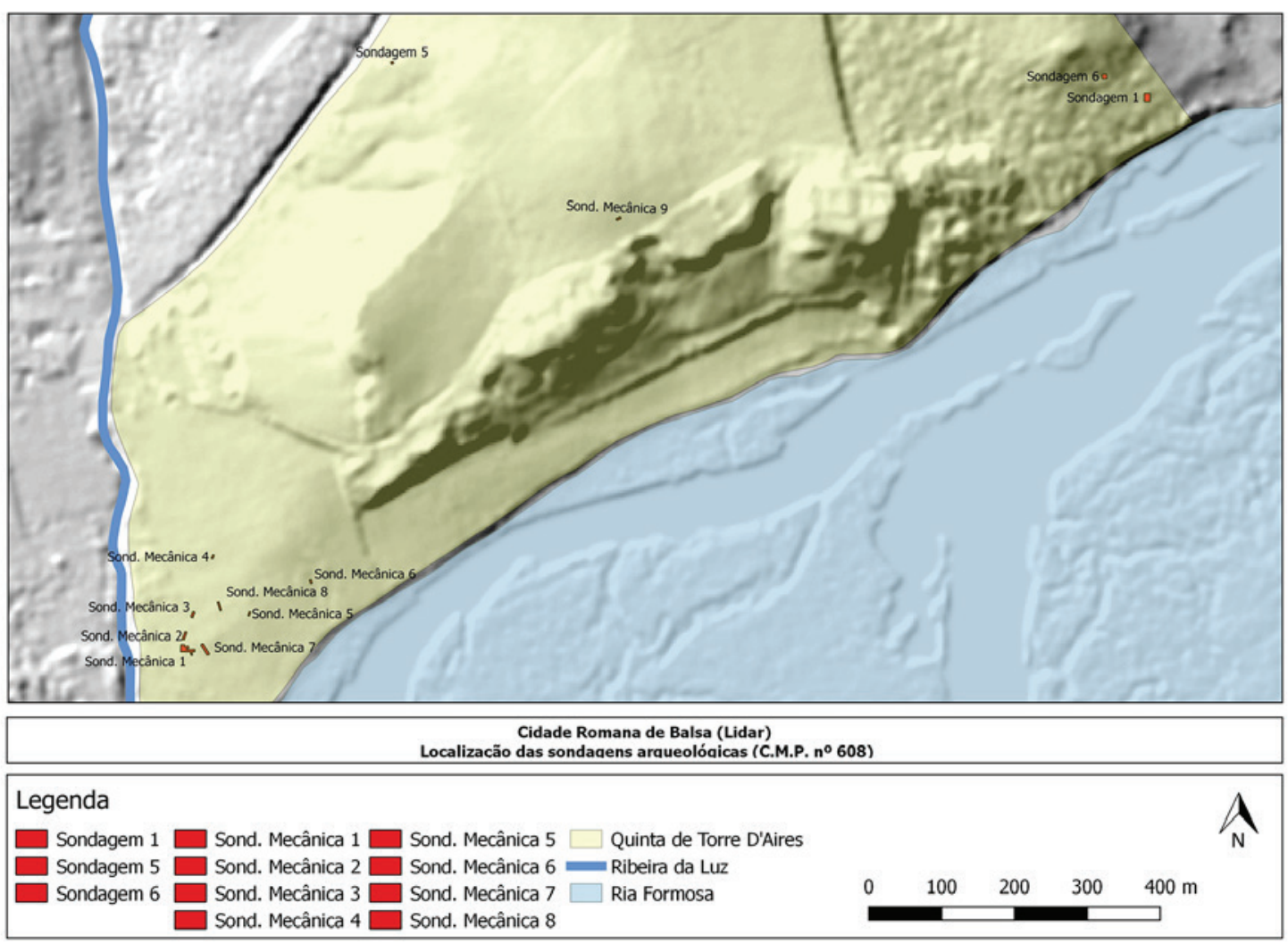

Figura 1 - Localização das sondagens manuais (S) e das sondagens mecânicas (SM).

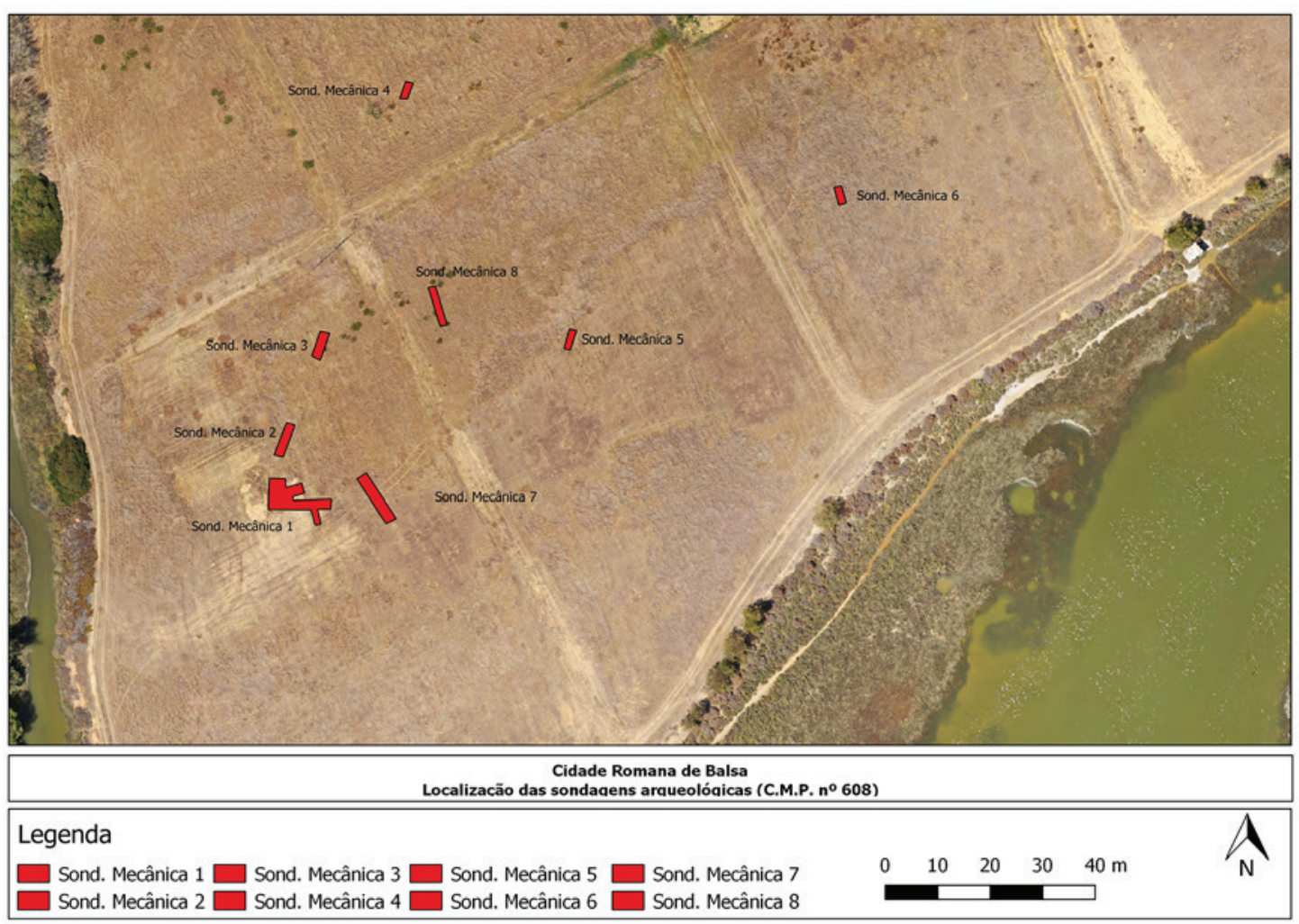

Figura 2 - Localização das mecânicas (SM1 - SM8). 


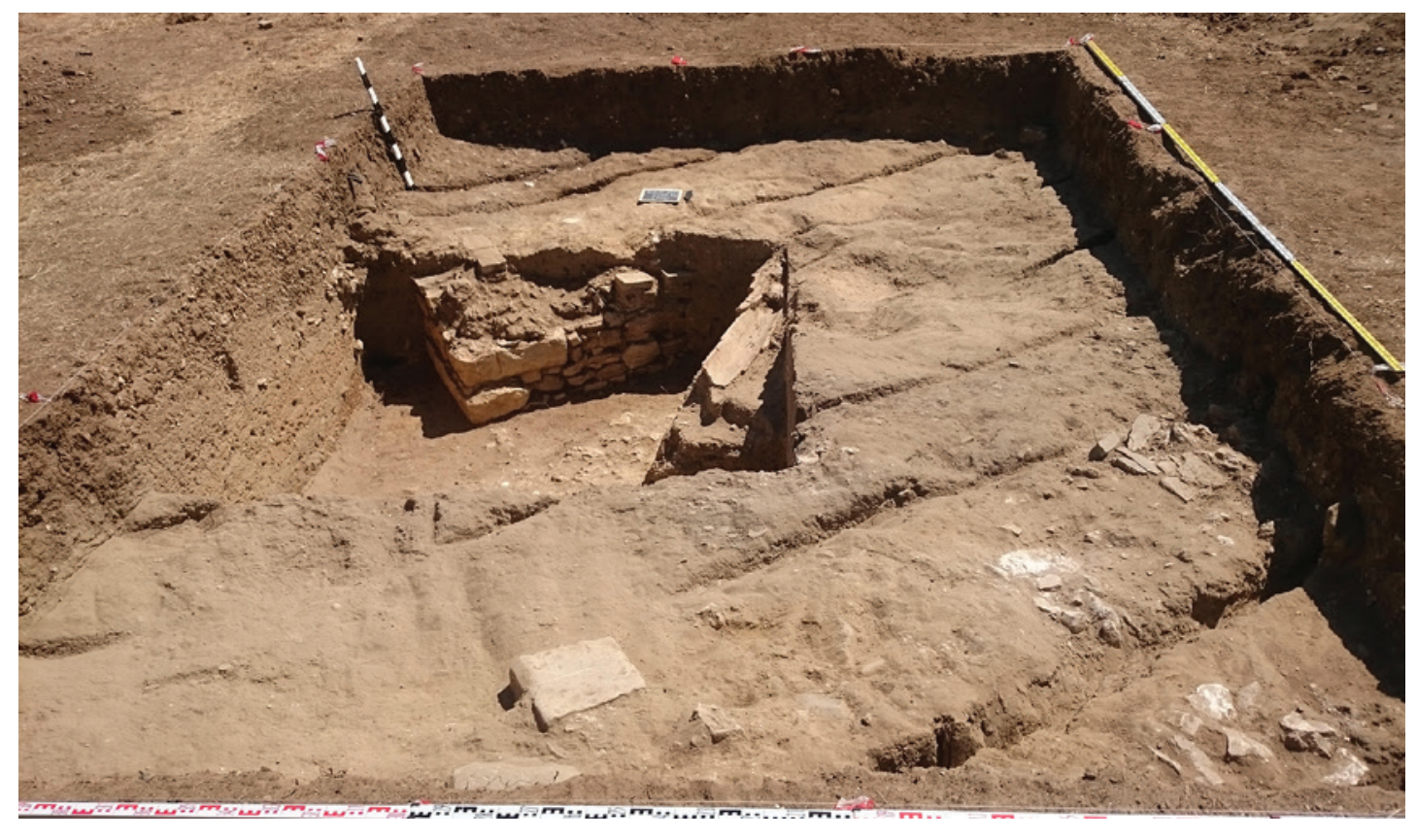

Figura 3 - Alargamento da Sondagem 1.

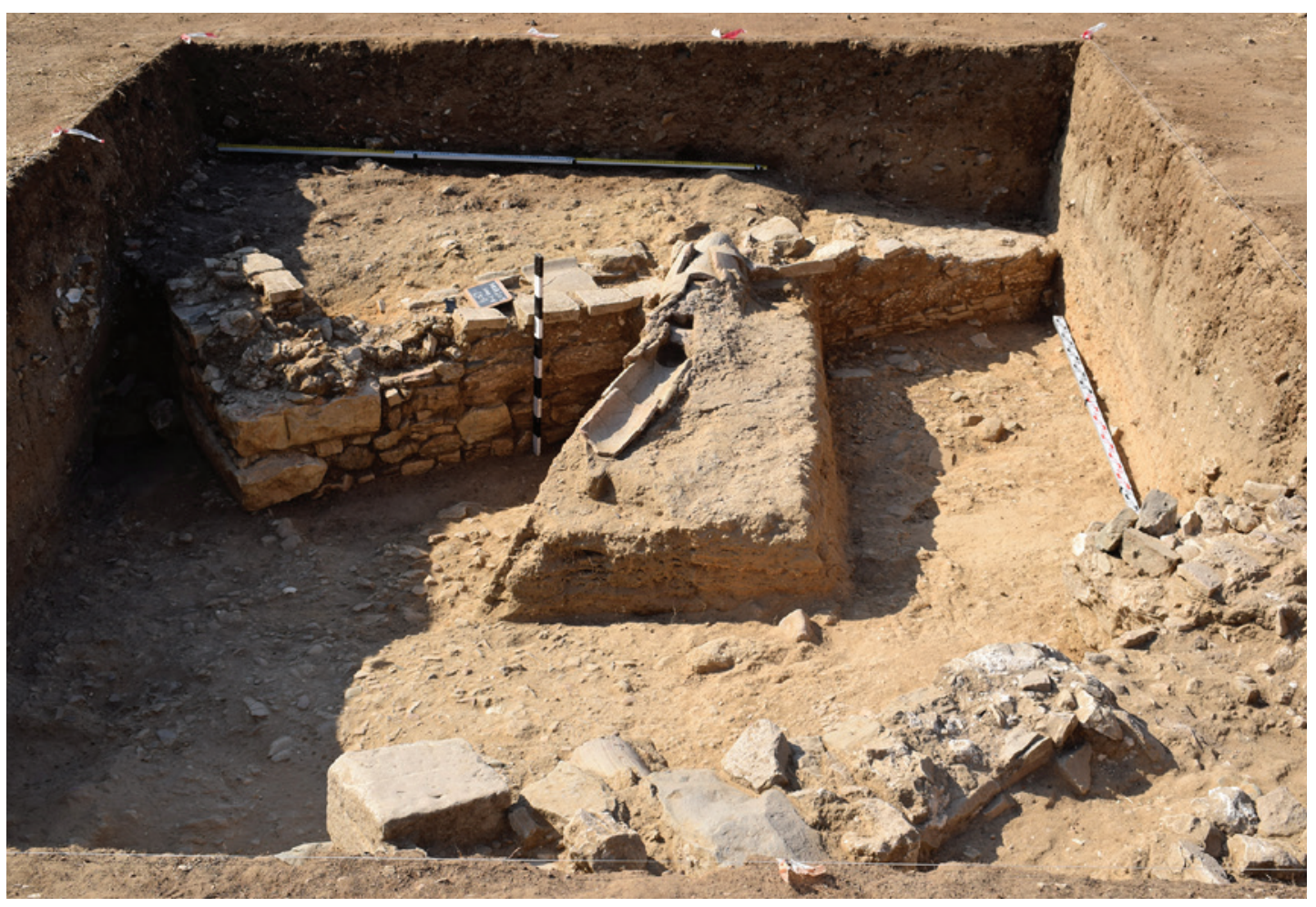

Figura 4 - Figura 6 plano final da sondagem 1. 

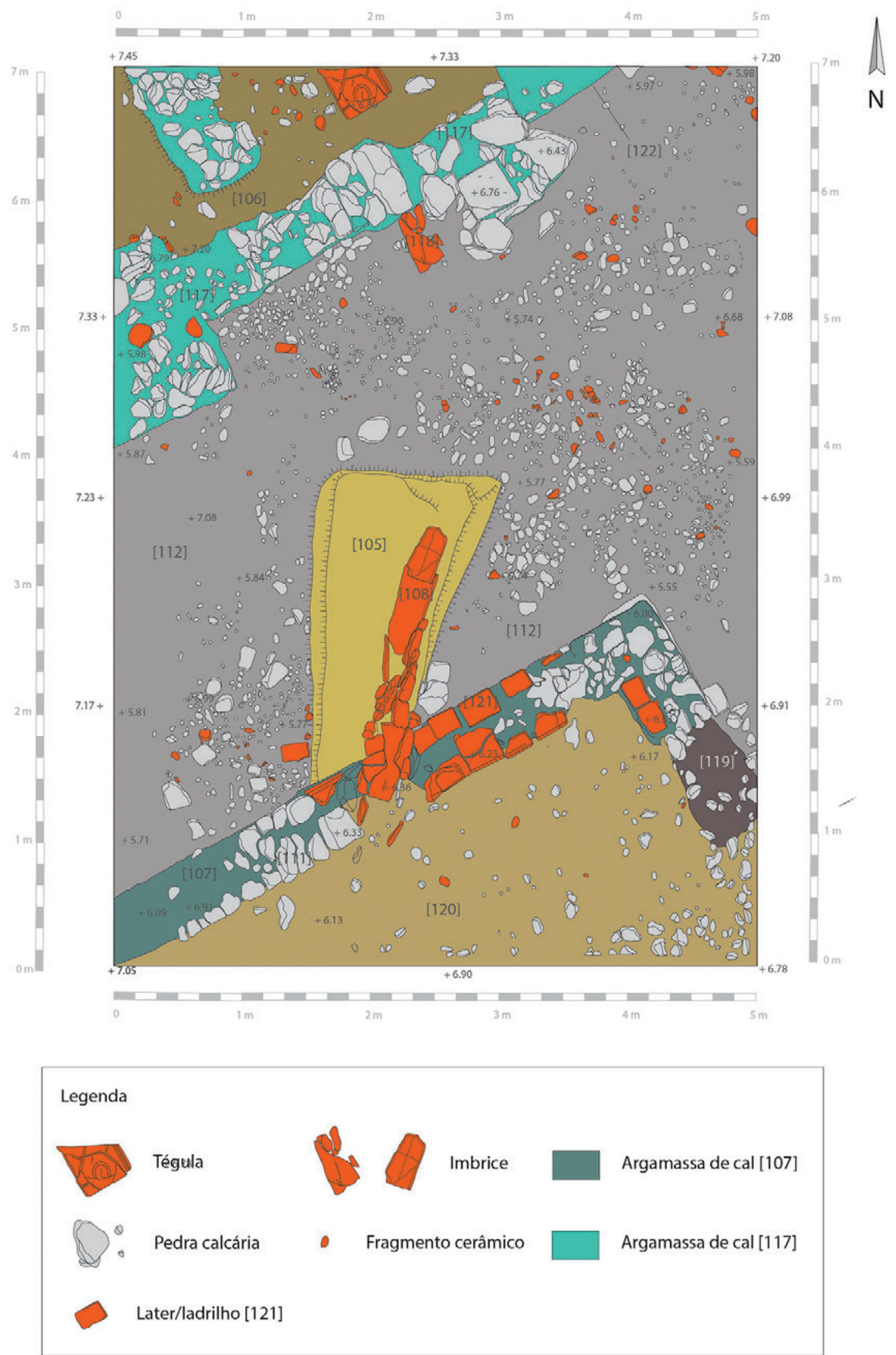

Figura 5- Plano final da sondagem 1. 


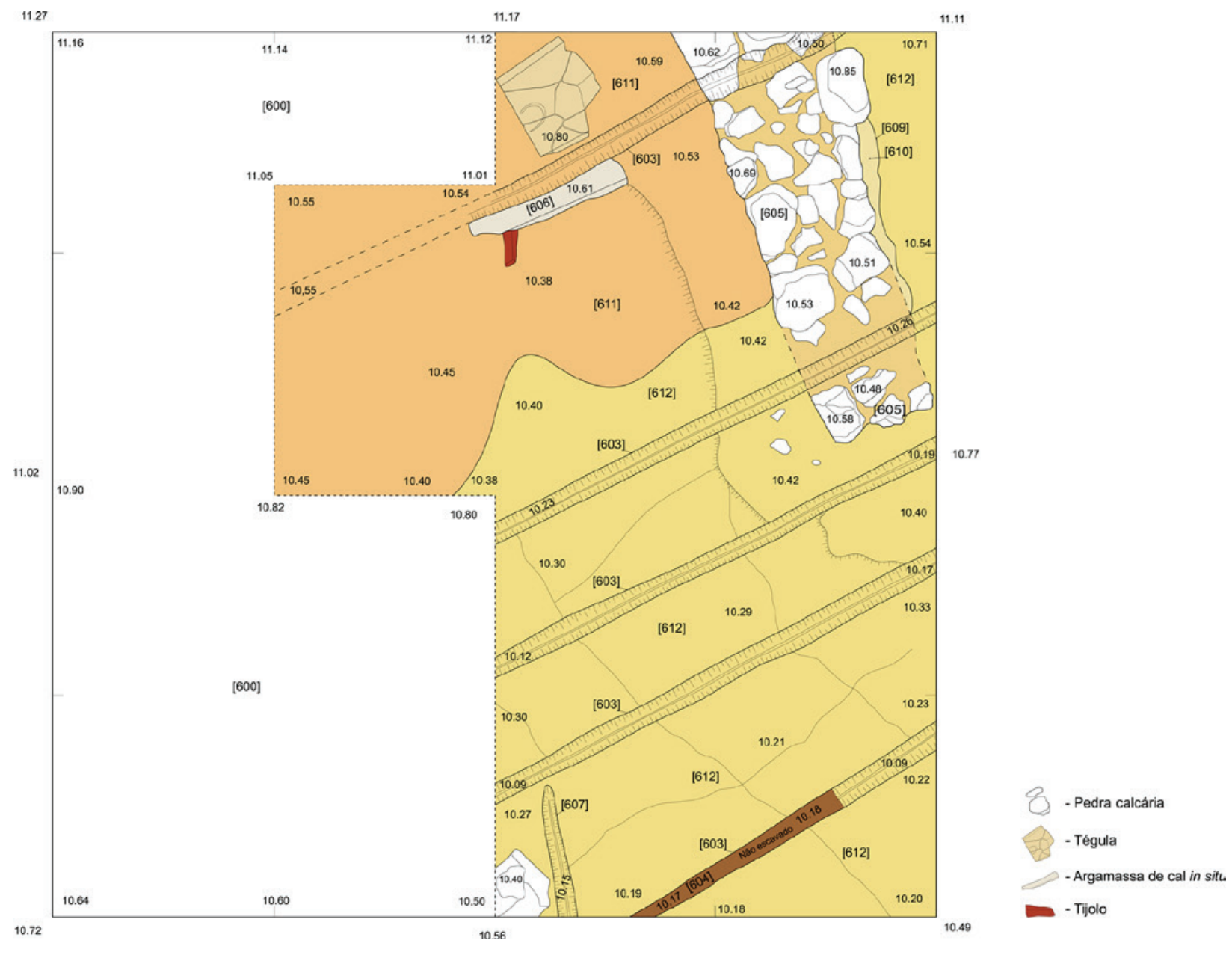

Figura 6 - Plano final da sondagem 6.
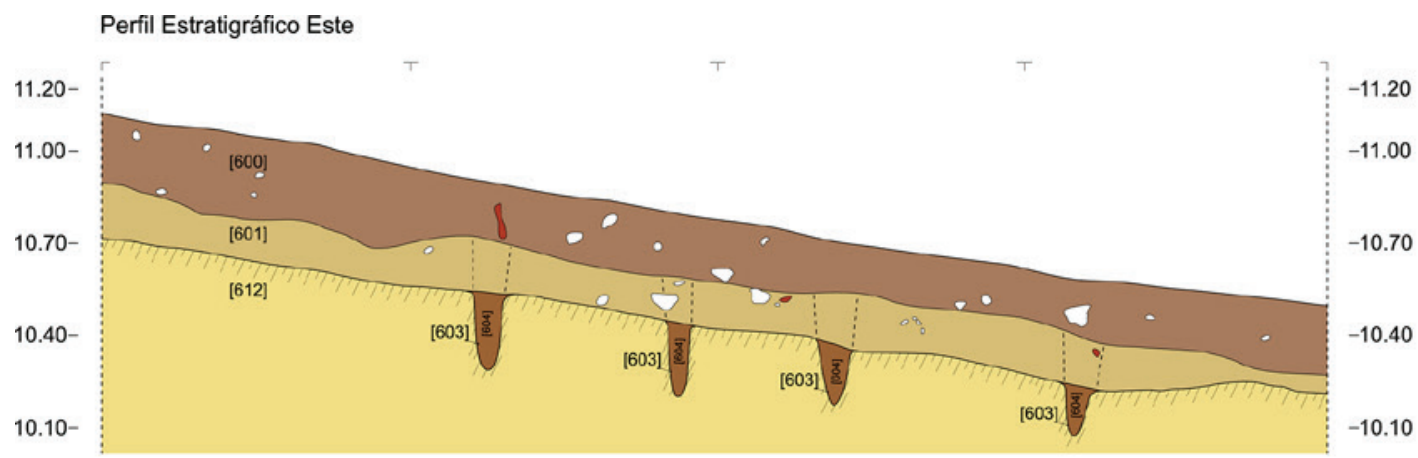

30. Pedra calcárie
2 - Cerămica

$-10.10$

Figura 7 - Perfil estratigráfico Este da sondagem 6. 


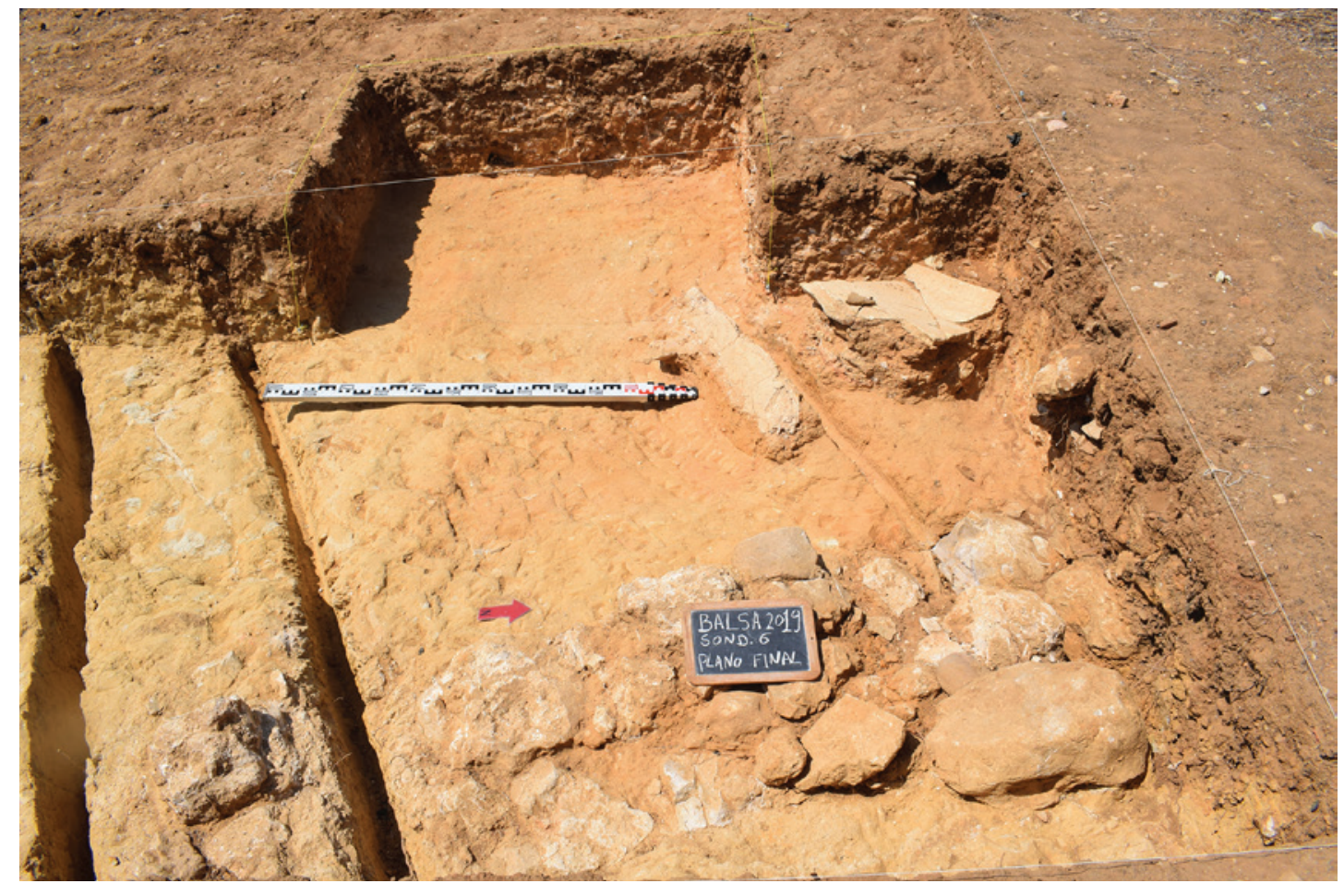

Figura 8 - Pormenor dos sulcos de ripper da sondagem 6 (plano final).

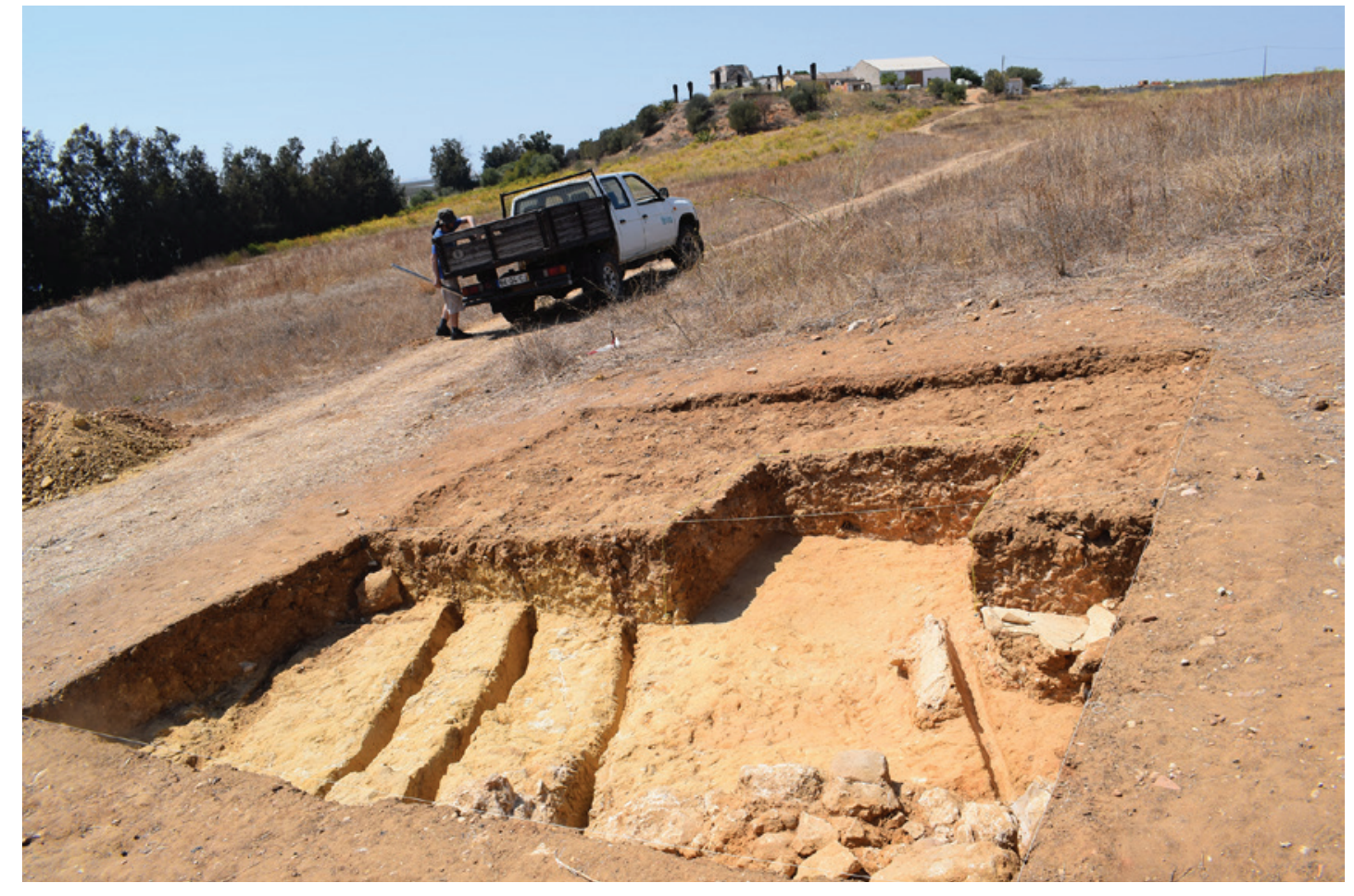

Figura 9 - Enquadramento geral da sondagem 6. 


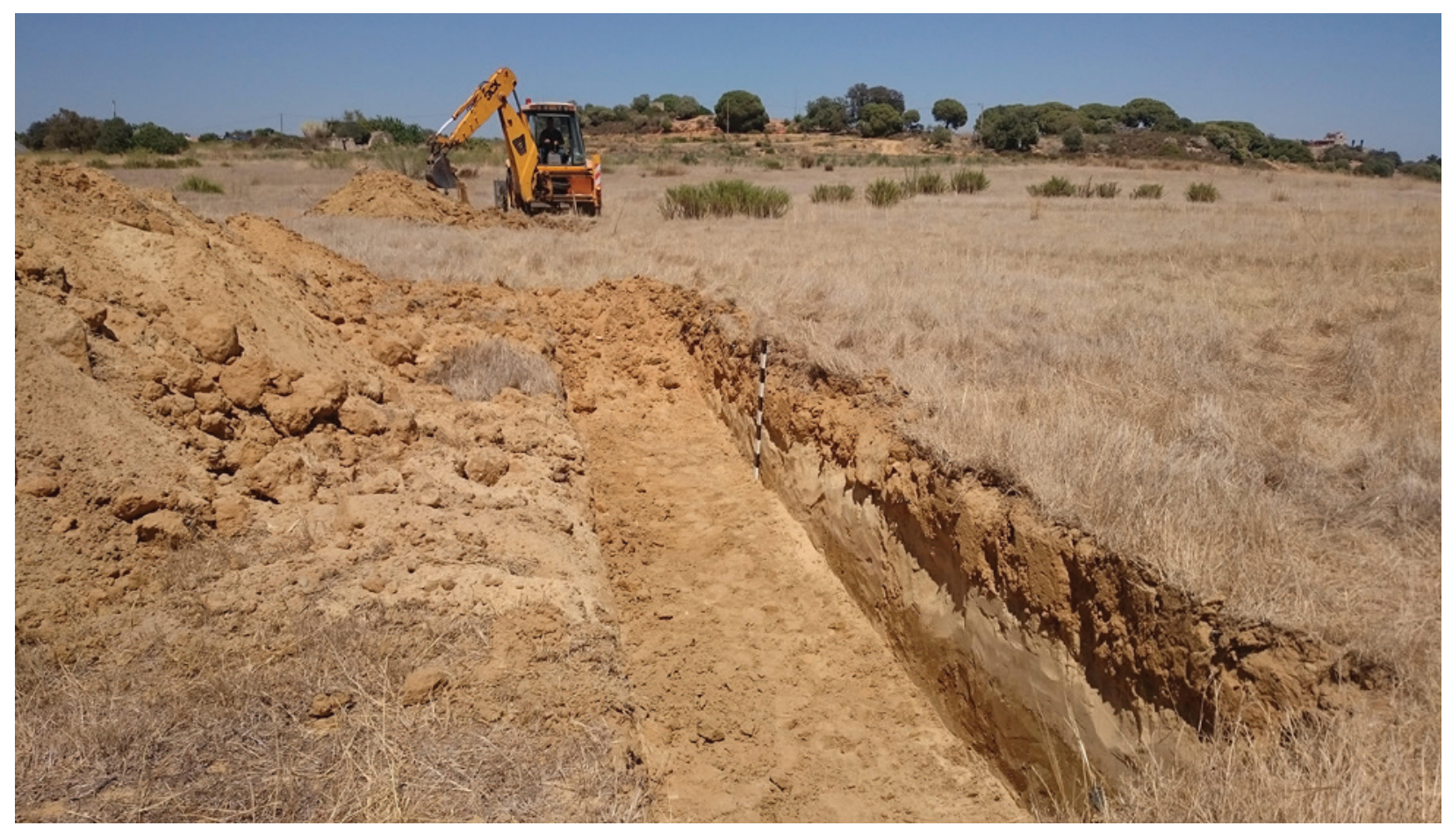

Figura 10 - Sondagens mecânicas (SM): abertura da SM 2. 



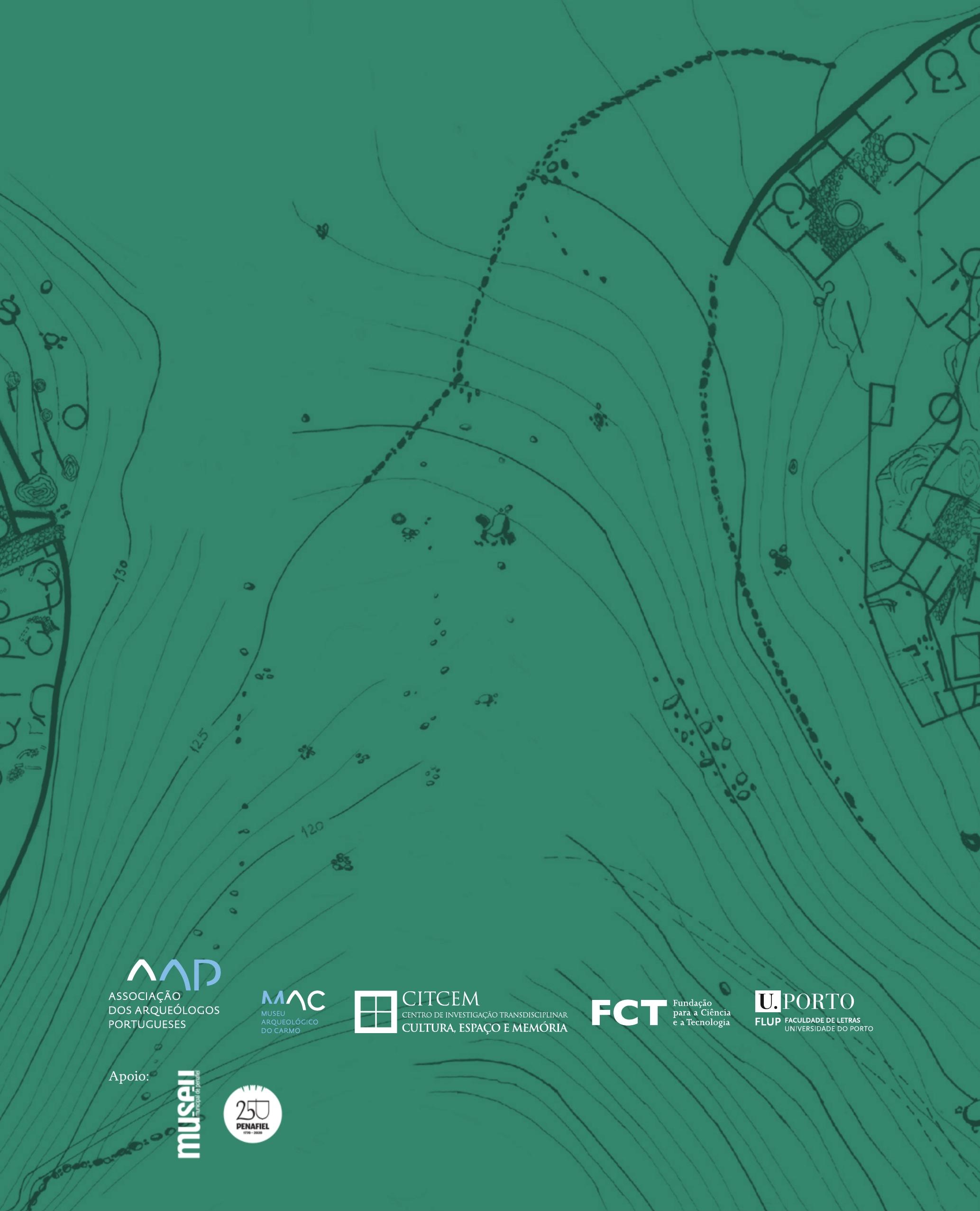

